1 Cite as: Yakovleva, N., Chiwona, A.G., Manning, D.A.C., and Heidrich, O. (In Press).

2 Circular economy and six approaches to improve potassium life cycle for global crop 3 production. Resources Policy, 102426.

\title{
Circular economy and six approaches to improve potassium life cycle for
}

\section{global crop production}

\section{ABSTRACT}

The United Nations Sustainable Development Agenda 2030 calls for a transformative action to eradicate hunger and poverty and is particularly important for food production in developing countries (see SDG 1 Zero Hunger). Farmers in developing countries apply less potassium fertiliser than those in developed countries due to the high cost of imports and unavailability of domestic supplies. A circular economy approach can improve the efficient use of potassium resources throughout their life cycle from "mine to mouth" by identifying problem areas and assisting in designing supply strategies that help address the needs of farmers. As a nutrient, potassium conventionally follows a linear life cycle from mining. Using secondary data sources and literature, we analyse global demand and supply of potassium to quantify and illustrate the major supply shortages in the Global South.

This study identifies six options to improve potassium availability: (1) expanding conventional

21 potassium mining and distribution systems serves those who can afford globally-traded

22 fertiliser products; (2) seeking alternative sources of potassium, such as remineralisers, that provide a local source that is accessible to poorer farmers, and in many cases helps the circular 
economy of local mining operations that focus on other products; (3) improving markets by supporting trade and mitigating some of the disadvantages encountered in developing countries, such as transport and small scale of purchasing; (4) increasing the use of organic fertilisers, such as sewage and manures; (5) reusing crop residues and other farm wastes as sources of potassium, regarding a farm unit as a closed system as far as is practicable; and (6) recycling food waste so that nutrients return to the land, rather than to discard. Existing restrictions and practices mean that there is no single solution to enhance food production in the Global South using the circular economy principles. However, if these circular economy principles and policies are considered at farm to country scale progress can be made.

KEYWORDS: Fertiliser; Potassium; Circular economy; Food system; Global South

\section{Introduction}

Potassium (K) and phosphorus $(\mathrm{P})$ are minerals produced through conventional mining and are key components of agricultural fertilisers that form essential inputs for plant growth and global food production. In the context of global population growth, fertiliser use is projected to rise due to surging demand for food and arable land (Weinzettel et al., 2013; Wu et al., 2018), biofuels and agricultural produce (Dmitrieva et al., 2017). Attention to date has focused on phosphorus (Cordell et al., 2009), with less paid to potassium availability. A lack of potassium supply is particularly concerning for the Global South (Sheldrick and Lingard, 2004), where domestic potassium production and effective potassium recovery from farming and food waste are largely absent (Ciceri et al., 2015). Lack of potassium poses significant social and economic challenges for poor small-holder farming communities in developing countries of the Global South that seek to improve soil quality, food production, farming yields and incomes, health, 
and nutrition in line with the United Nations Sustainable Development Goals (UN SDGs) (FAO, 2016; UN, 2016).

Besides the research on market mechanisms and searches for indigenous sources of mined potassium, there are gaps in academic research examining potential solutions to the supply of potassium in the Global South (Manning, 2010; FAO, 2016). There is a scarce understanding of how developing countries can advance fertiliser production and leapfrog from inefficient production patterns to a sustainable economy, achieving green growth and resources melioration (FAO, 2019; Vazquez-Brust and Sarkis, 2012). Here, the circular economy (CE) can offer valuable mechanisms and principles by revisiting the produce-use-dispose stages of production (Blomsma and Brennan, 2017; Luthra et al., 2019; Upadhyay et al., 2021a) to replace wasteful production methods of conventional industrialised production patterns. The circular economy is capable of advancing economic prosperity and the achievement of the UN SDGs by promoting systems thinking within production and consumption cycles, improving linkages between industrial sectors, reducing waste, and improving resource efficiency. Often studies examine fertiliser flows within a bounded agri-food system (Kelly, 2006; Carraresi et al., 2018). Though some studies establish a connection between food and mineral production when discussing mineral-based fertilisers, they seldom address the needs and contexts of the developing nations (Manning and Theodoro, 2020; Villalba et al., 2008; Wellington and Mason, 2014).

Thus, this paper aims to examine solutions to improve the supply of potassium, especially in developing countries. The paper has specific objectives to: a) define the potassium life cycle as an integrated system of food and mineral production; b) identify solutions to improving potassium fertiliser supply using CE principles and life cycle assessment in production, application, and recovery of potassium (Blomsma and Brennan, 2017; Braungart et al., 2007; Gaustad et al., 2018; Korhonen et al., 2018); and c) discuss barriers for circular economy 

limitations.

implementation in developing countries, making policy recommendations for overcoming these In order to respond to the special issue call on "Resources Melioration and Circular Economy" (Luthra et al., 2019), the analysis presented in the paper seeks to understand: a) the connections between mineral resource production and food production in the context of potassium fertilisers; b) the extent to which CE principles can close loops in the potassium life cycle; and c) barriers and drivers for reforming potassium supply in the Global South and building a sustainable potassium life cycle. The novelty of this study lies in detailing the extent of potassium shortages in the Global South, designing an extended view of the potassium life cycle from mineral production to farming, identifying possible solutions to overcoming potassium fertiliser shortages in developing countries and discussing enablers, and challenges for $\mathrm{CE}$ adoption in the context of potassium.

The paper is structured as follows. First, the paper reviews how the literature on CE relates to mineral production and potassium supply for food production. After outlining the adopted research methods, the paper examines potassium demand and supply conditions and presents the analysis of six approaches for improving supply using CE principles. Finally, the paper discusses the challenges to $\mathrm{CE}$ implementation in developing countries and provides policy recommendations.

\section{Literature Review: Circular Economy and Potassium Supply}

This section reviews how circular economy principles can be applied in mineral production and specifically in the production and supply of potassium, traded as the commodity 'potash'.

\subsection{Circular economy and mined minerals}


95 Circular economy (CE) is an economic system that offers an alternative to the current unsustainable production system that follows a linear production-use-disposal model by closing the loop with reuse and recycling of waste for further effective production and use (Geissdoerfer et al., 2017; Korhonen et al., 2018; Upadhyay et al., 2021a,b). CE is based on several principles such as resource efficiency, reuse and recycling of materials (Ellen MacArthur Foundation,

100 2013; 2019; Murray et al., 2017; RSA, 2013). It offers an arsenal of solutions to closing the loop of the production cycle through resource recycling, reuse, remanufacturing, refurbishment, repair, upgrading and associated use of low-carbon energy flows of solar, wind, and biomass (Bridgens et al., 2018; Korhonen et al., 2018; McDonough and Braungart, 2002).

104 Currently, CE is seen as an umbrella concept that embraces various related concepts. These include life cycle assessment, industrial ecology, industrial symbiosis, closed-loop production, waste management, reverse logistics, waste to energy, reduce-reuse-recycle, industrial parks, cradle-to-cradle, sustainable product design, resource efficiency, and optimisation, and extended producer responsibility (Braungart et al., 2007; Blomsma and Brennan, 2017; Winans et al., 2017). Though CE principles have entered policies and operations of public, private, and

110 non-governmental organisations, it is not certain how CE concepts are contributing to 111 improving production models in developing countries (Ellen McArthur Foundation, 2019; EU, 112 2014; EU, 2015; Lieder and Rashid, 2016).

113 With regards to mined minerals, Breure et al. (2018, p. 1127) argue that "the aim of the circular economy is to reduce the demand for fresh mineral resources, thereby reducing the negative impacts from mining and waste disposal on biodiversity and the quality of the human habitat."

116 CE principles can be applied to the production of metals and minerals in several ways. Firstly, 117 reduction in the use of metals and minerals can be achieved through changes in product design, 118 increased efficiency in the use of metals and minerals, and the recycling and reuse of metals and minerals from industrial, construction, and urban wastes (EU, 2018). For instance, nation- 
states develop regulations on waste to capture metals at the end-of-life of electric and electronic

121 equipment, construction, and other urban and industrial wastes for further effective use (Rhee, 122 2016; EU, 2018; UNEP, 2018). Secondly, CE principles can be used by mining and

123 metallurgical enterprises to exchange resources (e.g., water, heat, energy, and waste) with other

124 enterprises through industrial symbiosis initiatives to improve resource efficiency (Dong et al., 125 2013; Winans et al., 2017). Thirdly, all materials produced in mining, including the by126 products, can be marketed, sold, and utilised in order to maximise income and minimise waste 127 and energy (Kinnunen and Kasonen, 2019).

128 However, the policy imperatives for metal recycling and reuse do not necessarily lead to the 129 end of virgin non-renewable resource extraction. Powered by the growing economic 130 development globally and coupled with sequestration of materials before they enter waste 131 streams again, the demand for extraction of metals and minerals from the Earth's crust is steady 132 (Meinert et al., 2016; Ali et al., 2017; Tangtinthai et al., 2019). Production and use of future 133 technologies (such as renewable and low-carbon energy technologies, e-transport, and

134 electronic and electrical equipment) are associated with the consumption of metals and minerals 135 such as rare earth minerals (Manning et al., 2019). This raises concerns about the reliance of

136 future development on mineral extraction and warns of environmental and social dangers 137 associated with extraction processes such as resource depletion, environmental pollution, 138 impact on biodiversity, and both social and community impacts (Bridge et al., 2018; Sanchez139 Lopez, 2019). Further, Upadhyay et al. (2021a, 2021b) identify various barriers to the 140 implementation of circular economy such as institutional (e.g., regulation) and market factors 141 (e.g., demand and supply), organisational and cultural barriers, and financial, economic, and 142 technological barriers. 
144 Potassium (K) is a key component of commercial agricultural fertilisers that improve soil 145 quality and crop yields along with other irreplaceable nutrients necessary for plant growth, 146 nitrogen and phosphorus (Al Rawashdeh and Maxwell, 2014; Ciceri et al., 2015; IPI, 2016;

147 USGS, 2016; Heidrich et al., 2018). Humans and animals require potassium intake as part of 148 their diets to maintain health; it is essential for maintenance of body fluid volume, acid and 149 electrolyte balance, and normal cell function ${ }^{1}$ (WHO, 2012). Potassium is naturally found in 150 soils and is applied in agriculture with organic fertilisers (such as crop residues, compost, and 151 manure) and inorganic fertilisers (potassium fertilisers made from mined potash and other 152 geological materials) (PDA, 2008; 2016).

153 Currently, as much as $90 \%$ of mined potassium, derived from geological salt deposits, is used

154 for fertiliser production. The rest is used in industrial water treatment, animal feed supplements, 155 cement, fire extinguishers, and textile production (BGS, 2011; Al Rawashdeh and Maxwell, 156 2014). In agriculture, the use of mined potassium fertiliser increased since the onset of industrial 157 agricultural systems in the 1950s-1960s and discoveries of mineral potassium deposits in 158 Germany and Canada (Al Rawashdeh and Maxwell, 2014; Ciceri et al., 2015; Al Rawashdeh et 159 al., 2016).

160 In the light of sustainable developmental priorities expressed by the UN SDGs such as SDG2 161 Zero Hunger, SDG8 Decent Work and Economic Growth, and SDG12 Responsible 162 Consumption and Production (UN, 2016); efficiency of food production, especially in 163 developing countries, needs to be improved. Effective farming can help improve the livelihood 164 of poor, small-holder farming communities in the Global South, eradicate hunger and improve 165 health and nutrition. To achieve these SDGs, it is essential to advance the agricultural systems

\footnotetext{
${ }^{1}$ Normally ingested potassium leaves the human body through urine (WHO, 2012).
} 
166 in developing countries, and particularly increase the availability of affordable potassium

167 fertilisers for farmers in the Global South (Manning, 2010; Martey et al., 2019).

168 However, there is a dramatic lack of domestic potassium production in the Global South as the 169 majority of potassium is currently mined in the Northern hemisphere (Canada, Belarus, Europe, 170 and Russia) (Ciceri et al., 2015). Grantham (2012) urges that the world community cannot avoid 171 addressing the future regional shortages of mined fertilisers - phosphorus and potassium. If we 172 take a global view, the reserves of potash are not immediately scarce (USGS, 2016) and 173 available reserves will last for the next 400 years at the current consumption rate (Jasinski, 174 2011). However, future demand for potassium fertilisers will come predominantly from 175 countries in the Southern hemisphere and is linked to expected population growth in Asia, 176 Africa, and South America. The solutions to regional shortages of potassium fertilisers are not 177 well studied and require further investigation (Sheldrick and Lingard, 2004).

\section{Research Methods}

The paper aims to identify the current and projected demand and supply challenges in the regions, maps the shortages in developing regions, and identify approaches to overcome supply

182 challenges using the CE principles, especially the life cycle assessment view (see Figure 4). In order to achieve these aims, the study: a) reviews the existing trends in potash production and consumption worldwide and identifies the extent of potash deficiency in developing countries of the Global South using secondary data and visualisation of these trends using maps; and then b) identifies six approaches to improving the supply of potassium fertilisers in developing

187 countries by examining the potassium lifecycle and application of CE principles in order to close the loop. 
189 The study adopts an overall positivist approach, with realist ontology and objectivist 190 epistemology (Bryman and Bell, 2015). Whilst the analysis of quantitative secondary data is 191 based on geostatistical and spatial analysis (see Achilleos, 2011; Setianto and Triandini, 2013);

192 the analysis of textual secondary data and literature uses a deductive approach (Irwin, 2013; 193 Borrego et al., 2009). Conceptually, the study applies the principles of circular economy and 194 life cycle assessment to the study of potassium supply (Blomsma and Brennan, 2017; Braungart 195 et al., 2007; Gaustad et al., 2018). The study utilises secondary data on a) production and 196 consumption of potash, reserves, and resources (e.g., USGS, 2019; Sheldrick, 2001); b) demand 197 for fertilisers (e.g., FAO, 2019); and c) population distribution (e.g., UN, 2018). Following 198 Wellington and Mason (2014), this research determines whether the current level of global 199 production, reserves, and resources can meet the future demand for potassium fertiliser by geographical regions.

For the development of maps using ArcGIS 10.6 software, the paper uses data on the production and consumption of potash worldwide reported by Sheldrick (2001), Sheldrick et al. (2002), and Sheldrick and Lingard (2004) who constructed soil nutrient balances at national, regional and

204 global scales. The methodology for calculating nutrient balances, reported by Sheldrick and 205 Lingard (2004), involves detailed calculations of nutrient losses (e.g., leaching, erosion, and 206 gaseous) and gains (atmospheric deposition and sedimentation) through specialised models such as 207 a universal soil loss equation. These soil nutrient balances were calculated on the basis of published 208 data on crops, fertilizer, manure, and nitrogen from FAO databases (FAOSTAT, 2001; Sheldrick 209 and Lingard, 2004).

210 Maps were generated using the inverse distance weighting (IDW) interpolation method to produce 211 raster surface maps showing the K nutrient dynamics for different countries as reported by Sheldrick 212 (2001). The IDW method is a geostatistical and spatial analysis technique that works on the premise 213 that spatial points are locationally interdependent and points which are spatially close to each other 
214 are more similar than those far apart (Achilleos, 2011; Setianto and Triandini, 2013). The IDW

215 interpolation was used to define the cell values using a linearly weighted combination of a set of $\mathrm{K}$

216 nutrient sample points over each country's total area. The result from this processing was a raster

217 surface map showing the K nutrient dynamics for the different countries.

218 In order to identify the approaches to improving potassium supply, we use the process suggested

219 by Gaustad et al. (2018), whereby information is collected from academic literature as well as 220 insights gathered through interaction with the industry, including at the $2^{\text {nd }}$ International 221 Workshop on Alternative Potash in June 2017 (https://conferences.ncl.ac.uk/alternativepotash222 iwap/). Conceptual and statistical information about flows of potassium along the stages of 223 lifecycle was combined with information from circular economy literature to provide insights 224 about which circular economy principles are the most applicable to overcoming shortages of 225 potassium. A variety of technological and economic opportunities and constraints are reported 226 under each identified approach gathered from academic studies.

227 Using the review of existing academic studies on potassium production and consumption, we 228 depict the potassium lifecycle from mining of potash to food production and consumption 229 stages and demonstrate the movement of resources through the stages. Through "closing the 230 loop" on the movement of resources and applying the principles of circular economy (Blomsma 231 and Brennan, 2017), we identify and describe potential avenues for improving the supply of 232 potassium for fertiliser production in the Global South. Here, we propose six such approaches 233 to improve the fertiliser supply, application, and recovery in import-dependent countries of the 234 Global South. Finally, the paper discusses the potential challenges and limitations of scaling up 235 these six suggested solutions.

\section{Results}




\subsection{Potassium demand and supply in developing countries}

The global demand for fertiliser nutrients (expressed as $\mathrm{N}+\mathrm{P}_{2} \mathrm{O}_{5}+\mathrm{K}_{2} \mathrm{O}$ ) is increasing at $2.6 \%$ per annum (FAO, 2019) (see Table 1). This trend is associated with increasing consumption of animal protein (Roberts, 2009), fresh fruits and vegetables (Al Rawashdeh et al., 2016; FAO, 2016), and biofuel production (USGS, 2009; Canter et al., 2015), in the context of rising economic affluence and population growth (Weinzettel et al., 2013). The USGS (2019) forecasts that world potash consumption will increase from 42.2 million tonnes in 2018 to 46.2 million tonnes in 2022 with major demand coming from Africa (demand growth at $3.6 \%$ per annum), South America (2.9\% per annum), and Asia (2.9\% per annum) (Heffer and Prud'homme, 2016). With global reserves of potash $\left(\mathrm{K}_{2} \mathrm{O}\right)$ at 3.7 billion tonnes and new largescale production of polyhalite ${ }^{2}$, current potassium production rates appear to meet the global demand (USGS, 2016).

\begin{tabular}{llllll}
\hline Nutrients & 2015 & 2016 & 2017 & 2018 & 2019 \\
\hline Nitrogen $(\mathrm{N})$ & 112,539 & 113,955 & 115,498 & 116,905 & 118,222 \\
Phosphate $\left(\mathrm{P}_{2} \mathrm{O}_{5}\right)$ & 42,113 & 42,865 & 43,785 & 44,652 & 45,527 \\
Potash $\left(\mathrm{K}_{2} \mathrm{O}\right)$ & 31,973 & 32,802 & 33,629 & 34,452 & 35,257 \\
Total & 186,625 & 189,622 & 192,912 & 196,009 & 199,006 \\
\hline
\end{tabular}

Table 1: World demand for fertiliser nutrients $\left(\mathrm{N}+\mathrm{P}_{2} \mathrm{O}_{5}+\mathrm{K}_{2} \mathrm{O}\right)$ until 2019, thousand tonnes. Source: FAO, 2019.

Depletion of soil quality and land degradation is a major concern for human development and food security in developing countries. This is linked to agricultural and agronomical challenges, low per capita food production, poverty, slow economic development, and climate change effects (Sanchez, 2002; Gilbert, 2012; Mukuve and Fenner, 2015; Martey et al., 2019). Land degradation and especially potassium deficiency in sub-Saharan Africa (Sheldrick, 2001)

\footnotetext{
${ }^{2}$ Polyhalite can be used as multi-nutrient mined fertiliser that contains $\mathrm{K}$ in addition to $\mathrm{Mg}$, $\mathrm{Ca}$, and $\mathrm{S}$ (Pavuluri et al., 2017).
} 
continues due to overgrazing, soil erosion, and ineffective cropping systems (Mukuve and 259 Fenner, 2015; Wu et al., 2018). Inorganic fertilisers are applied at rates below recommended 260 levels causing serious losses in agricultural productivity (Sheldrick and Lingard, 2004).

261 Despite being a home to $15 \%$ of the global population, Africa accounts for $3 \%$ of the world's 262 fertiliser consumption and 1.9\% of potash consumption in 2013 (FAO, 2015). Authors argue 263 that increased application of potassium fertilisers and improved fertiliser management can 264 increase production yields, reduce soil degradation and tackle food nutrition challenges in 265 Africa (Bumb and Baanante, 1996; Larson and Frisvold, 1996; Sheldrick and Lingard, 2004). 266 Access to potassium fertilisers in sub-Saharan Africa is low and the continent solely depends on imports (Mukuve and Fenner, 2015; FAO, 2016). Market constraints for African farmers to access fertilisers include high prices, costly transportation, absence of large-scale potash mines, 269 and lack of domestic potassium production (Sanchez, 2002; Sheldrick and Lingard, 2004; 270 Ciceri et al., 2015; Al Rawashdeh et al., 2016; USGS, 2016; Martey et al., 2019). Figures 1-3 summarise the state of potassium demand and deficiency globally. Considering 272 population growth and distribution (UN, 2018 population data), the demand for increased 273 volumes of food supply will come from Asia, North America, South America, then Europe and 274 Africa in that decreasing order. As South Asia and Europe are more densely populated, these 275 regions would require more fertiliser input per unit area. Figure 1 shows that by 2001 most 276 soils worldwide were depleted in K. This means almost all countries globally need K inputs to 277 replenish their soil $\mathrm{K}$ depletion, which can mainly be attributed to soil mining through crop 278 growth. Greater focus needs to be on the more populous regions of Asia. Africa's population 279 has also been increasing at alarming rates and is expected to double from 1.1 billion in 2010 to 280 close to 2 billion in 2040, Therefore more efforts are also needed to increase $\mathrm{K}$ fertiliser inputs 281 in African soils. 


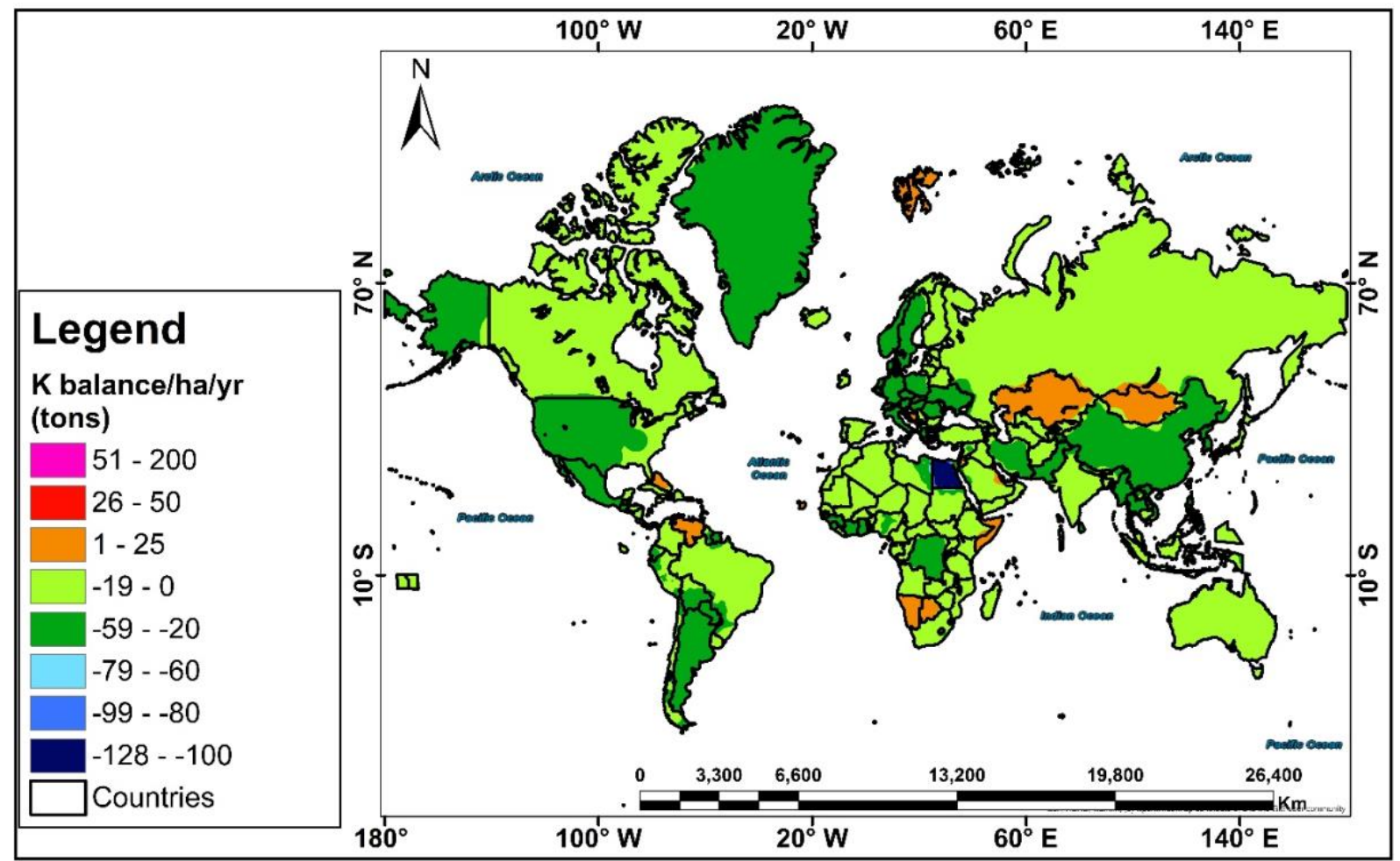

Figure 1. Annual soil potassium nutrients balance per hectare per year for globally, in tonnes from input, uptake and depletion from all sources. Source: Using data from Sheldrick (2001).

Figure 2 shows the total potassium nutrient inputs from all sources per unit area (tonnes $/ \mathrm{km}^{2}$ )

287 for different countries in 2002. However, as shown in Figure 2, only Europe and China seem to 288 be tackling the $\mathrm{K}$ fertiliser scarcity in relation to their population dynamics. Africa, South Asia 289 and North America, and Australia have low K nutrient inputs. Based on the population 290 dynamics and possible fertiliser demand, there is a greater need to increase $\mathrm{K}$ fertiliser 291 production and supply in the Global South. Figure 3 shows global K input from commercial 292 fertilisers by tonnage. There is very little K input from commercial fertiliser for Africa, Asia 293 and some parts of North America, and South America. China has higher fertiliser inputs 294 probably due to its economic strength. 


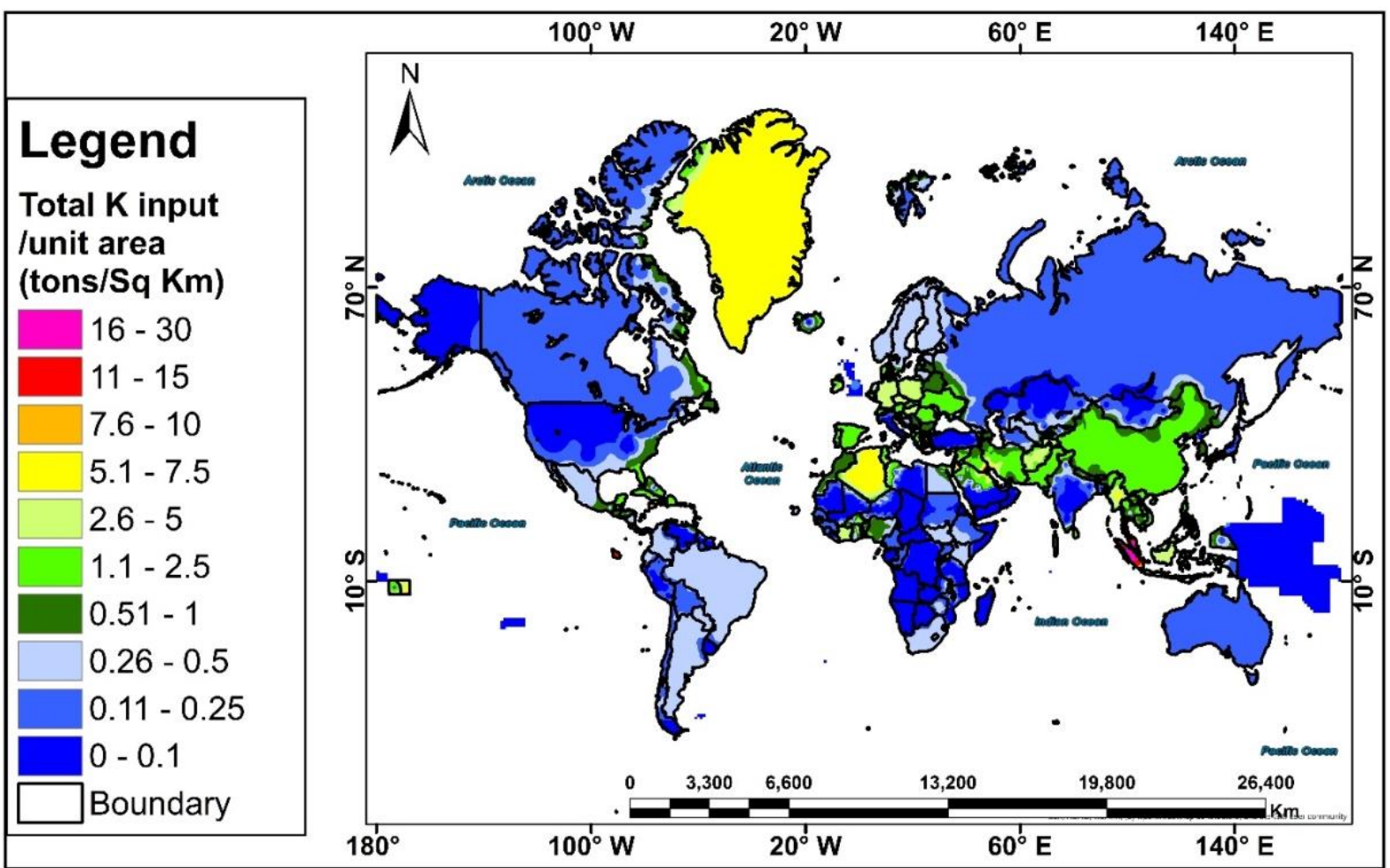

Figure 2. Total potassium nutrient inputs from all sources per unit area (tonnes $/ \mathrm{km}^{2}$ ) for different countries in 2002. Source: Using data from Sheldrick (2001).

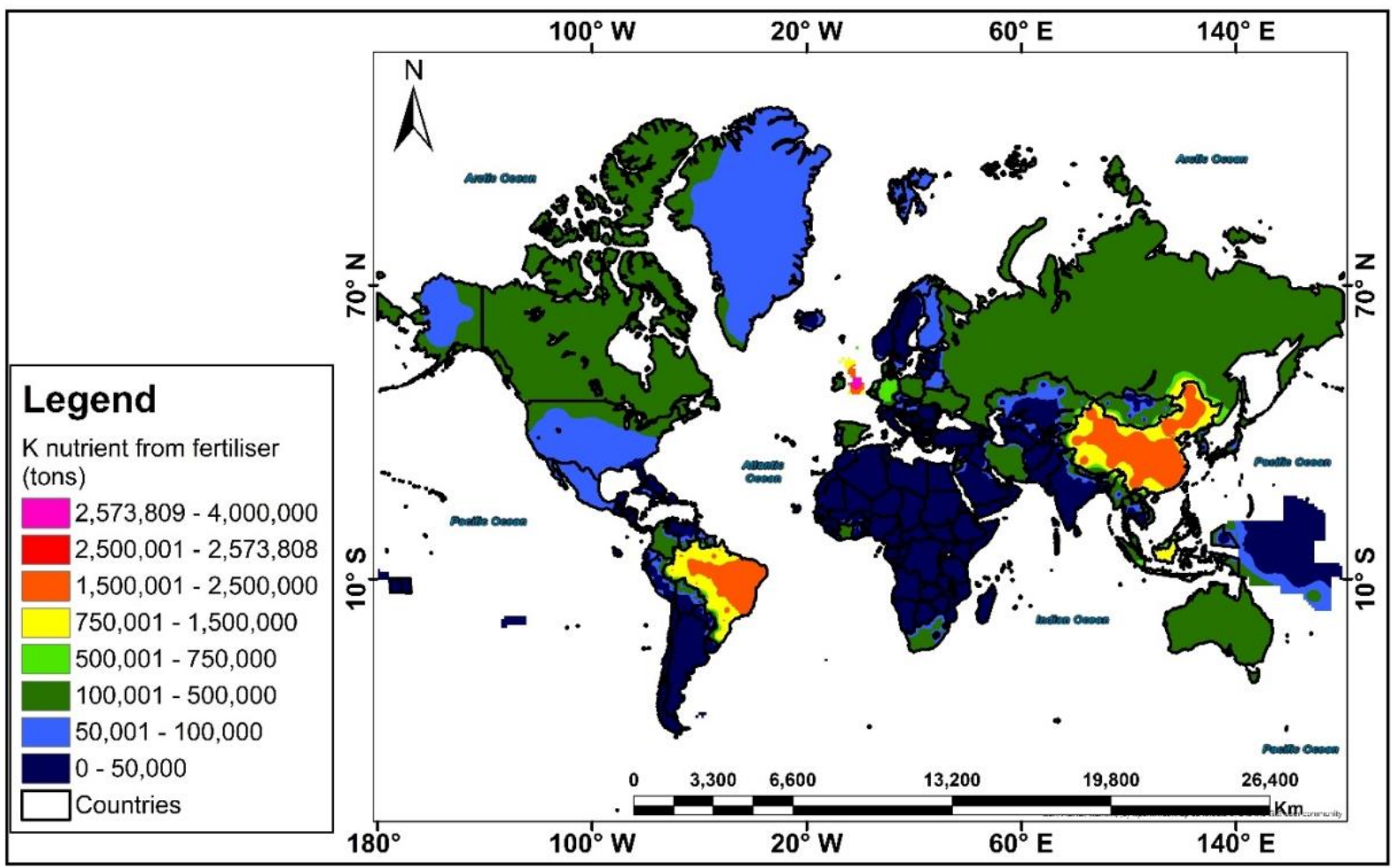

Figure 3. Potassium nutrients from commercial fertilisers input into the soil by farmers per country (in tonnes). Source: Using data from Sheldrick (2001). 
305 The potassium life cycle incorporates both mineral and food productions and the current system

306 is largely linear (see Figure 4). However, there are opportunities to close the cycle with the 307 application of CE principles and improving resource melioration, which are discussed below.

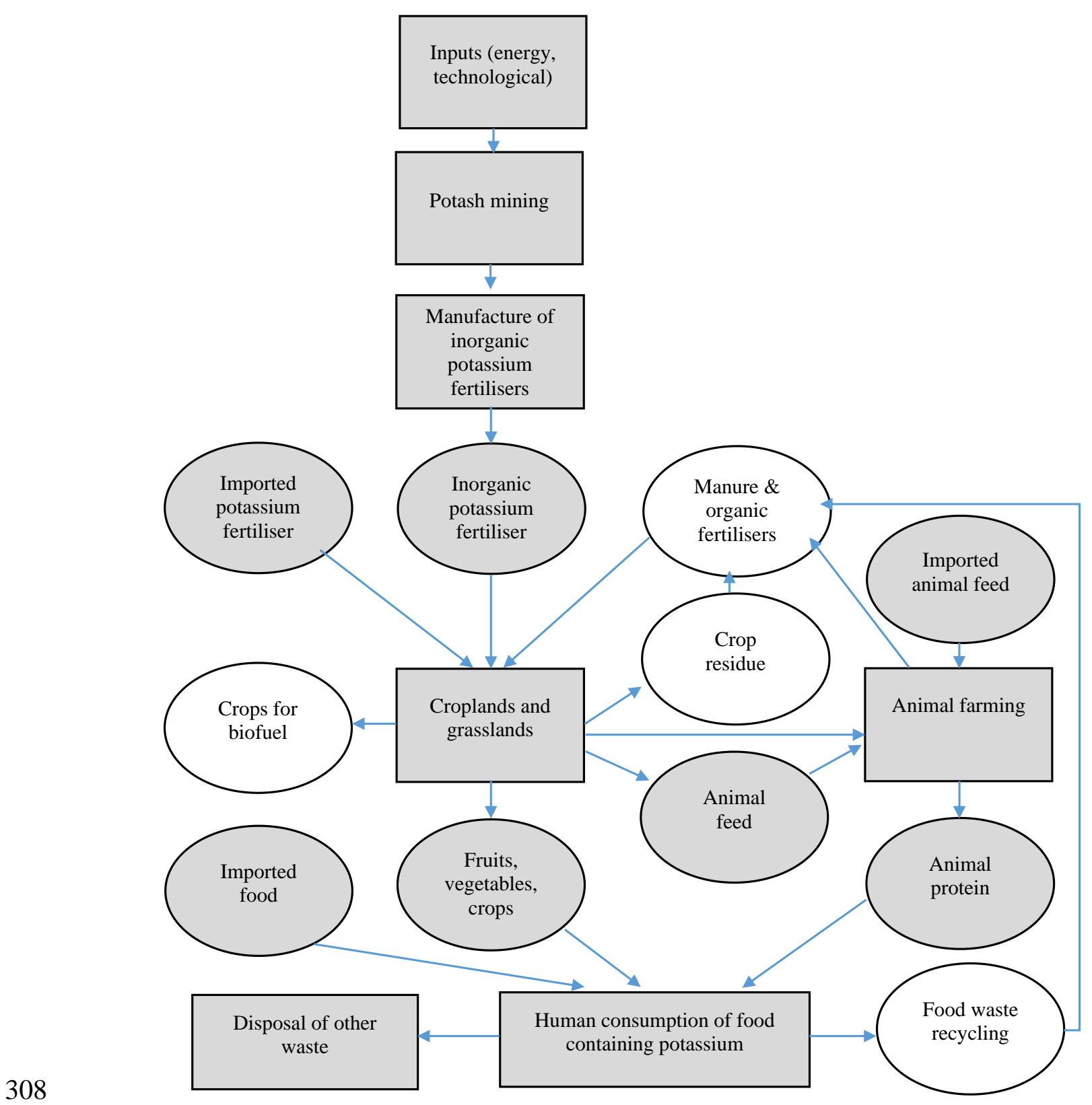

309 Figure 4: Potassium life cycle. Source: Authors own, adapted from Potash Development 310 Association $(2008,2016)$. Note: In shade are the dominant stages in the potassium life cycle. 
311 The study identifies six approaches to improve the supply of potassium fertiliser in the Global

312 South. First, improvement of geological information and searching for conventional potash

313 mineral deposits in regions such as Africa, Asia, and South America. The second approach

314 promotes a search for alternative, possibly unconventional, sources of potash in the Global

315 South that would be suitable for soils in tropical and sub-tropical climates. The third approach

316 focuses on improving the information on farm practices and improving the existing channels of

317 trade between potash producing nations and potassium-consuming nations. The fourth approach

318 encourages a reduction in using mineral fertilisers and promotion of organic fertiliser use in

319 large-scale agricultural production. The fifth approach calls for a systemic change and departure

320 from large-scale industrialised production to small-scale, close-cycle production where

321 fertiliser nutrients are produced from organic manures and farm wastes. Lastly, the sixth

322 approach looks at recycling all different types of food and farm waste to produce fertiliser

323 nutrients that contain potassium for use in agricultural production. The enablers and triggers of

324 each approach and the benefits for farmers in the Global South are examined below.

\subsubsection{Expand traditional production: search for conventional potash mineral deposits}

The traditional approach is to expand conventional potash production and develop mines in the

327 Global South that would form a supply basis for regional potassium fertiliser production.

328 However, almost all potash (this term refers to a number of different mineral salts that contain potassium $^{3}$ ) is mined in just 8 countries: Canada, Russia, Belarus, and Israel, followed by

smaller producers such as China, Germany, Jordan, and the US. In Europe, Germany, Spain,

\footnotetext{
${ }^{3}$ Potash is mined in various forms: potassium chloride ( $\mathrm{KCl}$ or muriate of potash), potassium sulphate $\left(\mathrm{K}_{2} \mathrm{SO}_{4}\right)$, potassium-magnesium sulphate $\left(\mathrm{K}_{2} \mathrm{SO}_{4} 2 \mathrm{MgSO}_{4}\right)$, and potassium nitrate $\left(\mathrm{KNO}_{3}\right)(\mathrm{Al}$ Rawashdeh and Maxwell, 2014; USGS, 2009). The mineral polyhalite $\left(\mathrm{K}_{2} \mathrm{Ca}_{2} \mathrm{Mg}\left(\mathrm{SO}_{4}\right)_{4} \cdot 2 \mathrm{H}_{2} \mathrm{O}\right)$ is a new multi-nutrient product $\left(14 \% \mathrm{~K}_{2} \mathrm{O}\right.$; Kemp et al., 2016), currently mined at one location in the UK (Boulby mine) with a new mine being built near Whitby (Anglo American, 2020). Potassium chloride $(\mathrm{KCl})$ is currently the main $\mathrm{K}$ fertiliser product, which contains about $60 \%$ of potash $\left(\mathrm{K}_{2} \mathrm{O}\right)$ equivalent. About $93 \%$ of the world's mined potash is used by the fertiliser industry (USGS, 2009).
} 
and the UK are the leading producers of potash (BGS, 2011; Table 2). The US Geological

332 Survey (2019) reports no large potash mines in Africa at the moment, but significant mines are 333 planned for development in Congo (Brazzaville) - Kola Project (Reuters, 2018), Eritrea 334 Colluli potash project (Forbes, 2019), and Ethiopia. Outside traditional potash-producing 335 countries, new potash mine projects are being planned in Argentina, Australia, Laos, and Peru, 336 and have been considered in Thailand (Hite and Japakasetr, 1979). Cumulatively, all new mines 337 and expansion of old mine projects are expected to increase world potash production capacity 338 to 64.6 million tonnes of $\mathrm{K}_{2} \mathrm{O}$ equivalent in 2022, which roughly corresponds to current use 339 plus the deficit reported by Sheldrick et al. (2002).

340 Geological exploration for commercially viable deposits of potash, including $\mathrm{K}$ as a component 341 of natural multi-nutrient fertilisers such as polyhalite, is conducted by private companies. The 342 potassium market is fairly small in terms of the number of actors; not only there are few 343 potassium-producing countries, but few large companies are operating in the market globally. 344 Al Rawashdeh et al. (2016) cite high barriers to entry in the potassium mining industry as it is 345 highly concentrated, which puts limitations to the expansion of the industry. Amongst the 346 largest producers of fertilisers is PotashCorp from Saskatchewan that has recently agreed to 347 merge with a smaller producer, Agrium, to create a crop nutrient group worth $\$ 30 \mathrm{bn}$ in market 348 capitalisation (FT, 2016a). Other producers include Mosaic (USA), Uralkali (Russia), 349 Belaruskali (Belarus), Yara (UK), Israel Chemicals (Israel and UK), and K+S (Germany) 350 (PotashCorp, 2014). Following the takeover of Sirius Minerals, Anglo American plc is building 351 the Woodsmith Mine in the UK to produce polyhalite; the new mine plans to have zero waste 352 (Anglo American, 2020). Israel Chemicals already produces polyhalite from the nearby Boulby 353 Mine (FT, 2016b). 


\begin{tabular}{llllllllllll}
\hline Country & $\mathbf{2 0 0 5}$ & $\mathbf{2 0 0 6}$ & $\mathbf{2 0 0 7}$ & $\mathbf{2 0 0 8}$ & $\mathbf{2 0 0 9}$ & $\mathbf{2 0 1 0}$ & $\mathbf{2 0 1 1}$ & $\mathbf{2 0 1 2}$ & $\mathbf{2 0 1 3}$ & $\mathbf{2 0 1 4}$ & $\mathbf{2 0 1 5 e}$ \\
\hline Belarus & 4,800 & 4,605 & 4,970 & 4,970 & 2,490 & 5,250 & 5,500 & 4,760 & 4,240 & 6,290 & 6,500 \\
Brazil & 405 & 405 & 405 & 471 & 385 & 453 & 454 & 425 & 430 & 311 & 311 \\
Canada & 10,120 & 8,360 & 11,100 & 10,500 & 4,320 & 9,788 & 11,000 & 8,980 & 10,100 & 11,000 & 11,000 \\
Chile & 370 & 450 & 500 & 559 & 692 & 800 & 980 & 1,050 & 1,050 & 1,200 & 1,200 \\
China & 600 & 600 & 2,000 & 2,750 & 3,000 & 3,200 & 3,700 & 4,100 & 4,300 & 4,400 & 4,200 \\
Germany & 3,600 & 3,620 & 3,600 & 3,280 & 1,800 & 3,000 & 3,010 & 3,120 & 3,200 & 3,000 & 3,000 \\
Israel & 2,060 & 2,200 & 2,200 & 2,300 & 2,100 & 1,960 & 1,960 & 1,900 & 2,100 & 1,770 & 1,800 \\
Jordan & 1,230 & 1,036 & 1,090 & 1,220 & 683 & 1,200 & 1,380 & 1,090 & 1,090 & 1,260 & 1,250 \\
Russia & 5,500 & 5,720 & 6,600 & 6,730 & 3,730 & 6,260 & 6,500 & 5,470 & 6,100 & 7,380 & 7,400 \\
Spain & 500 & 437 & 580 & 435 & 435 & 415 & 420 & 420 & 420 & 715 & 700 \\
UK & 600 & 480 & 427 & 427 & 427 & 427 & 427 & 470 & 470 & 610 & 610 \\
USA & 1,200 & 1,100 & 1,100 & 1,100 & 700 & 930 & 1,000 & 900 & 960 & 850 & 770 \\
Others & 65 & 65 & 12 & 11 & 12 & - & - & - & - & 50 & 50 \\
World & 31,100 & 29,100 & 34,600 & 35,000 & 20,800 & 33,700 & 36,400 & 32,700 & 34,500 & 38,800 & 38,800 \\
total & & & & & & & & & & & \\
Annual & $\mathrm{n} / \mathrm{a}$ & $-6.4 \%$ & $18.9 \%$ & $1.2 \%$ & - & $62.0 \%$ & $8.0 \%$ & - & $5.5 \%$ & $12.4 \%$ & $0 \%$ \\
growth & & & & & $40.6 \%$ & & & $10.2 \%$ & & &
\end{tabular}

354 Table 2. Global potassium producing countries, thousand metric tonnes. Source: US Geological 355 Survey (2016).

356 Note: $2015 \mathrm{e}$ - estimated output for 2015.

\begin{tabular}{lll}
\hline Country & Recoverable ore & K2O equivalent \\
\hline Belarus & $3,300,000$ & 750,000 \\
Brazil & 300,000 & 13,000 \\
Canada & $4,200,000$ & $1,000,000$ \\
Chile & $\mathrm{n} / \mathrm{a}$ & 150,000 \\
China & $\mathrm{n} / \mathrm{a}$ & 210,000 \\
Germany & $\mathrm{n} / \mathrm{a}$ & 150,000 \\
Israel & $\mathrm{n} / \mathrm{a}$ & 270,000 \\
Jordan & $\mathrm{n} / \mathrm{a}$ & 270,000 \\
Russia & $2,800,000$ & 600,000 \\
Spain & $\mathrm{n} / \mathrm{a}$ & 20,000 \\
UK & $\mathrm{n} / \mathrm{a}$ & 70,000 \\
USA & $1,500,000$ & 120,000 \\
Others & 250,000 & 90,000 \\
World total & $\mathrm{n} / \mathrm{a}$ & $3,700,000$ \\
\hline
\end{tabular}

357 Table 3: Global reserves of potash, thousand metric tonnes. Source: US Geological Survey 358 (2016).

359 Note: $\mathrm{n} / \mathrm{a}-$ data not available. 
362 Leonardos et al. (2000) and Ciceri et al. (2015) argue that alternative sources of potash need to 363 be sought that are suitable for deeply leached tropical soils in the Global South. Alternative 364 sources of nutrient $\mathrm{K}$ from locally occurring rocks and minerals can enable subsistence farmers 365 to use a range of rocks as remineralizers (Van Straaten, 2002; Manning and Theodoro, 2020). 366 Access to these avoids the major capital investment that is required to fund the exploration and 367 development of deep mining of conventional potash. There may be fewer market incentives and 368 less private funding available to develop major potash mines in the Global South for bulk 369 commodities (Ciceri et al., 2015; Al Rawashdeh et al., 2016). Instead, Leonardos et al. (2000) 370 argue that the adoption of large-scale commercial agriculture systems in the Global South, 371 following the paradigm of intensive agriculture borrowed from North America and Europe, 372 brings negative environmental consequences.

373 Given that the indigenous agricultural systems in the Global South maintained soil quality and 374 food production previously, Leonardos et al. (2000) support propositions for small-scale 375 agriculture that combine the use of inorganic or mineral fertilisers (such as phosphate or silicate 376 rock) with organic sources of nutrients for plant growth. In the context of the Global South, 377 Leonardos et al. (2000) promote an idea of using locally sourced fertilisers to support 378 subsistence and modern agriculture, bearing in mind that the majority of farm units are small 379 (in Brazil, only $10 \%$ of farm units produce the commodity crops that Brazil is famous for, and $38090 \%$ produce crops for domestic consumption (Manning and Theodoro, 2020). In such cases, 381 the 'stone meal' can be provided at low cost by local producers and small-scale miners; the use 382 of these materials is now embedded in Brazilian federal law through the regulation of 383 'remineralizers' (Manning and Theodoro, 2020).

384 Ciceri et al. (2015) and Leonardos et al. (2000) suggest that the search for alternative sources 
of potassium should be encouraged, as conventional soluble potassium fertilisers are not entirely appropriate for soils in tropical and sub-tropical zones. In many cases, the use of crushed rock as a remineralizer embeds a circular economy concept; many mines and quarries that produce crushed rock aggregate for the construction industry find that this creates a new market for 'crusher fines' that might previously have been regarded as a waste. In addition,

390 Figures 5-7 show K nutrient inputs into the soils using some alternative sources namely manure,

391 human sewage, and crop residues. In each case, China has better strategies for ensuring the use

392 of manure, sewage, and crop residues as alternative potash sources. There is very low utilisation 393 of manure as a K source in Africa, East Asia, and North America. Similarly, the least use of 394 sewage as alternative potash sources is in Africa, East Asia, and the Americas. The use of crop 395 residues as $\mathrm{K}$ sources is also least in Africa, East Asia, and some parts of Europe.

\section{Legend} $\mathrm{K}$ nutrient from Manure (tons)

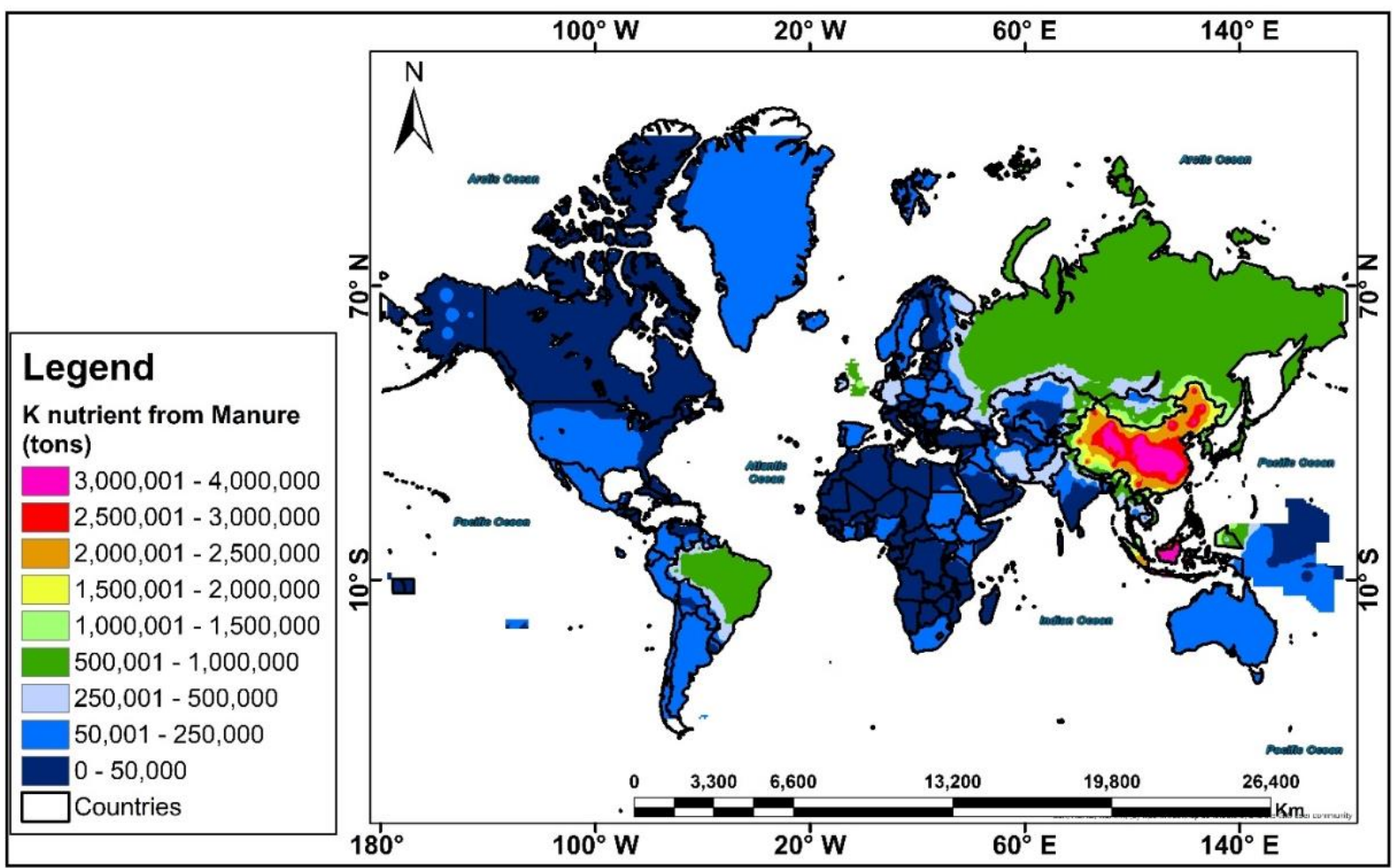

Figure 5. Potassium nutrients from manure input into the soil by farmers per country (in tonnes). Source: Using data from Sheldrick (2001). 


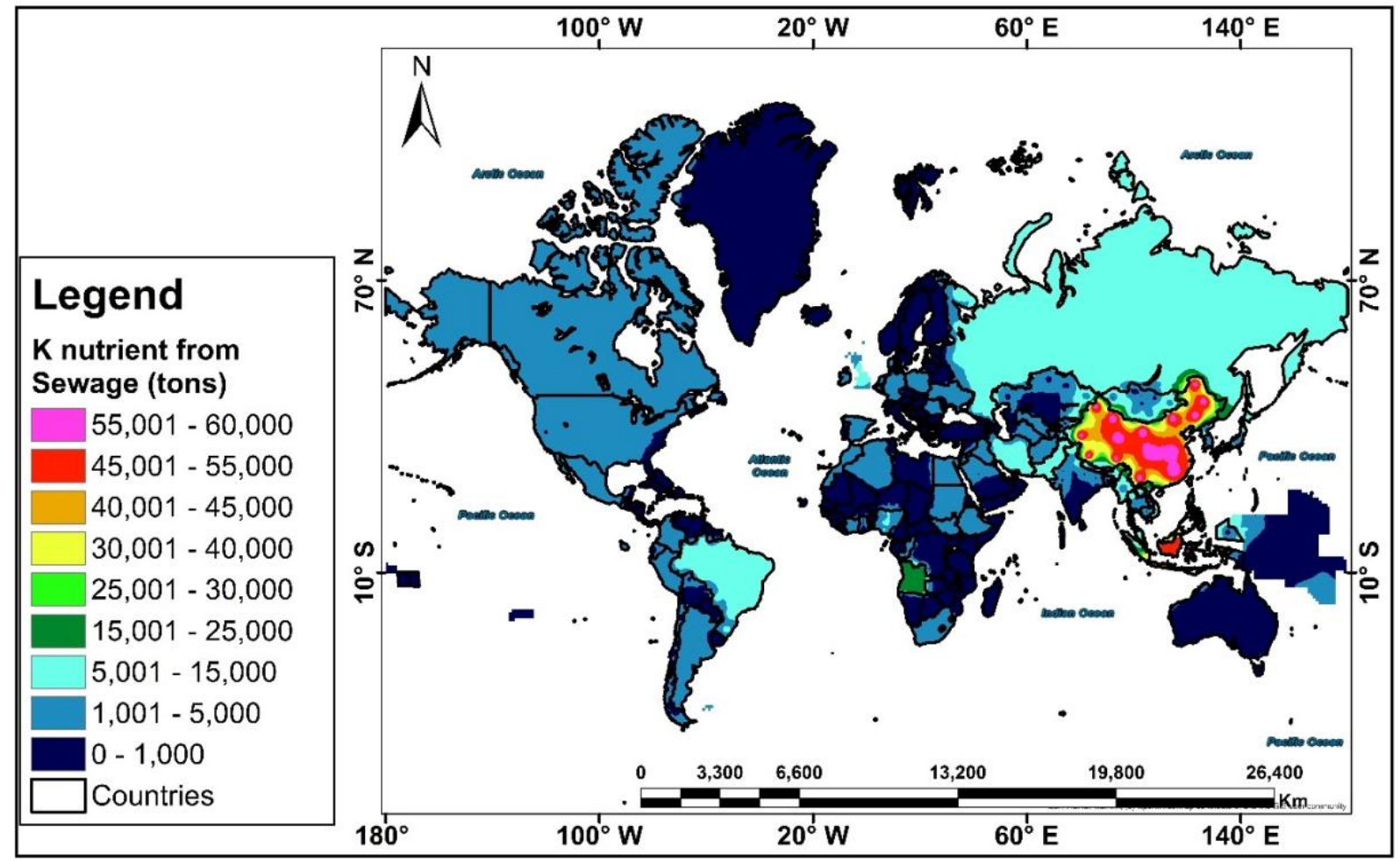

400 Figure 6. Potassium nutrients from sewage input into the soil by farmers per country (in 401 tonnes). Source: Using data from Sheldrick (2001).

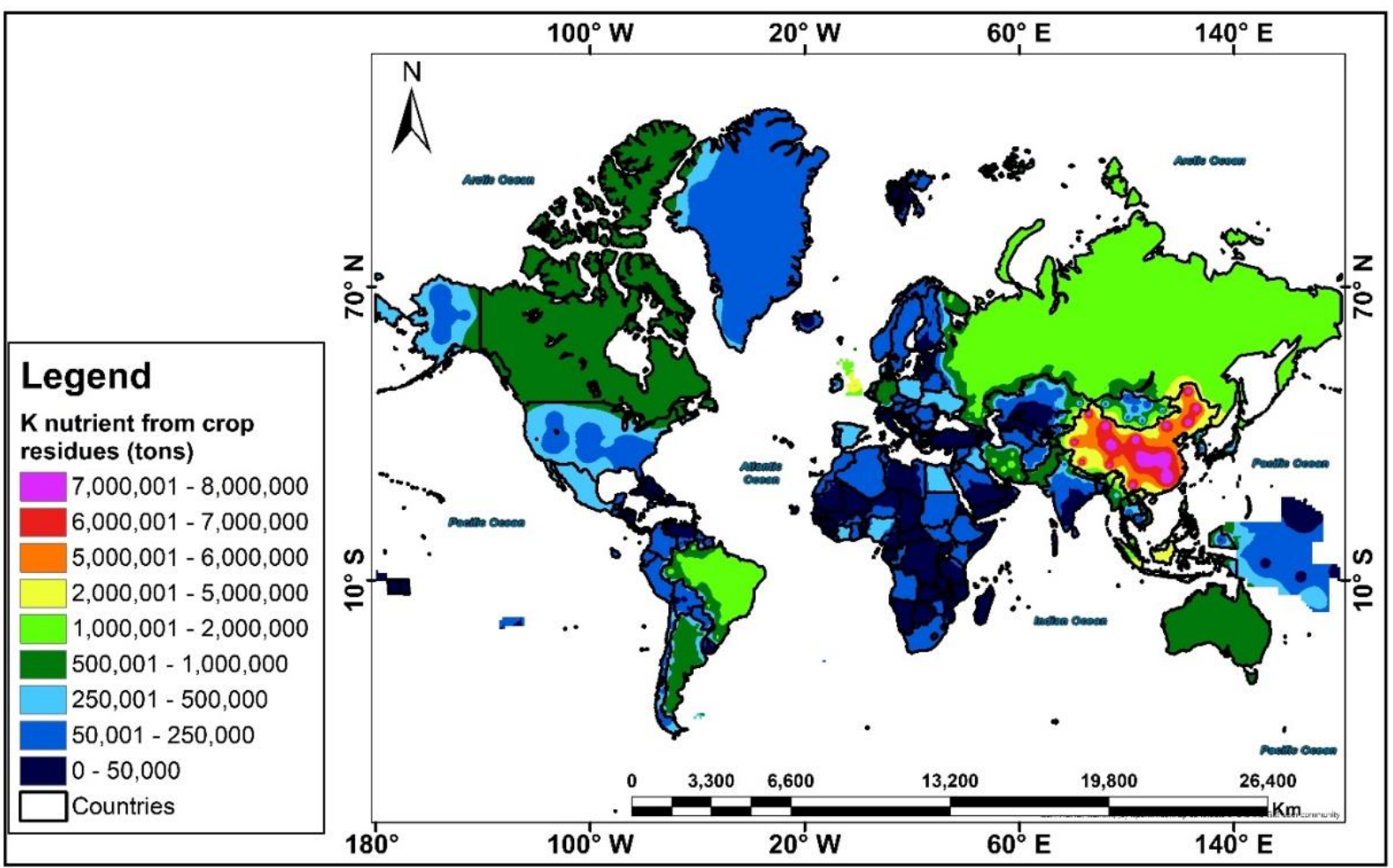

403 Figure 7. Potassium nutrients from crop residues input into the soil by farmers per country (in 404 tonnes). Source: Using data from Sheldrick (2001). 
406 The use of remineralizers, as pioneered by Brazil, involves the use of silicate rocks capable of 407 providing a range of elements. Those richest in $\mathrm{K}$ include feldspar and especially nepheline408 bearing rocks, which have been considered as sources of $\mathrm{K}$ for decades. The release of $\mathrm{K}$ from 409 these rocks depends on the dissolution rates of their component minerals, as explained by 410 Manning (2010). Although trials have been carried out in Norway (Bakken et al., 2000), silicate 411 rocks are better suited for use in tropical oxisols, where silicate minerals are inherently unstable, 412 with most successful trials being reported from these (Tavares et al., 2018).

\subsubsection{Improve markets: support of potassium fertiliser trade in developing countries}

414 In order to increase the availability of potassium fertilisers to farming communities and combat 415 soil degradation, improve soil fertility and assist inefficient local markets, governments in 416 developing countries have introduced fertiliser subsidy programmes, such as in sub-Saharan 417 Africa (Martey et al., 2019). Importing potassium fertilisers, poor availability of information, 418 costly transportation, and distribution all conspire to increase fertiliser prices, and contribute to 419 low fertiliser use and thus poor soil management. On average, African farmers pay between 30$42050 \%$ more than their counterparts in Europe and North America to purchase K fertiliser (Roberts 421 and Vilakazi, 2014). As a result, there is very little use of commercial fertilisers in Africa and 422 other similar parts of the Global South. Figure 8 shows the percentage of commercial fertiliser 423 input as a proportion of total inputs from all $\mathrm{K}$ sources, namely commercial fertilisers (Figure 424 3), manure (Figure 5), sewage (Figure 6), and crop residues (Figure 7). 


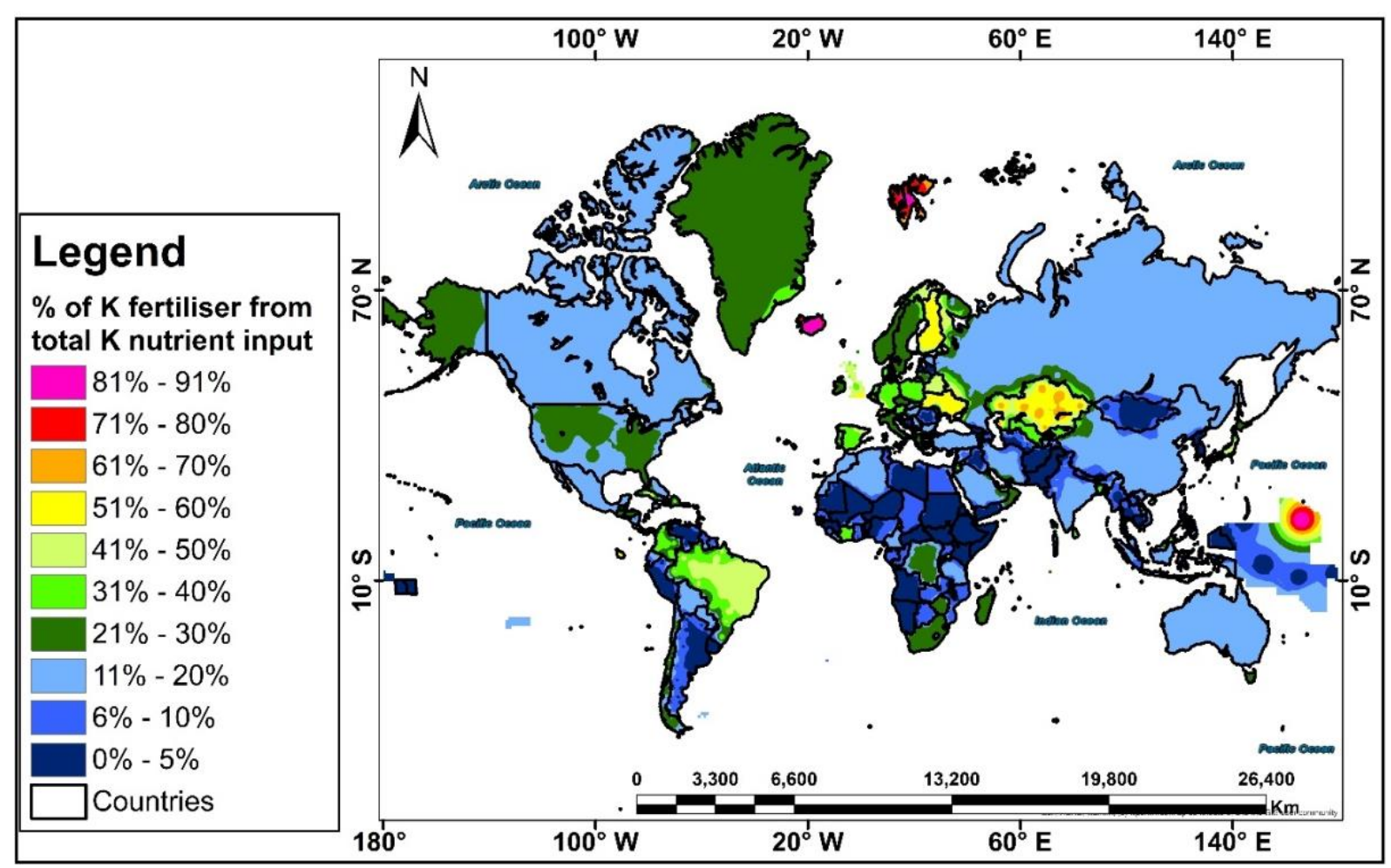

Figure 8. Percentage of potassium fertiliser over total input into the soil by farmers per country (in tonnes). Source: Using data from Sheldrick (2001).

It is clear in Figure 8 that for most countries in the Global South, less than $9 \%$ of total $\mathrm{K}$ nutrients input in their soils come from the conventional fertilisers. The average intensity of fertiliser use in sub-Saharan Africa is approximately $8-9 \mathrm{~kg} / \mathrm{ha}$, compared with $80 \mathrm{~kg} / \mathrm{ha}$ globally (Marquis et al., 2013; USAID and IFDC, 2015). The intensity has generally been highest in Southern (16 kg/ha) and Eastern ( $8 \mathrm{~kg} / \mathrm{ha})$ African countries and lowest in the Sudan Sahel (4 kg/ha) and Central Africa (3 kg/ha) (Kelly, 2006). On a household level, Sheahan and Barret (2017) (cited in Martey et al., 2019) report that based on a study of six African countries, inorganic fertiliser use across all households is the highest in Malawi (146 kg/ha), followed by Nigeria (128 kg/ha), Ethiopia (45 kg/ha), Tanzania (16 kg/ha), Niger (2.5 kg/ha), and Uganda $(1.2 \mathrm{~kg} / \mathrm{ha})$.

While about $65 \%$ of Africa's population were engaged in the agricultural sector by 2013 , the sector showed low productivity accounting for only $32 \%$ of the continent's gross domestic 
441 product (Marquis et al., 2013). This was largely due to inadequate fertiliser utilisation, 442 especially in smallholder farming. The various legislative frameworks operating in different 443 countries also contribute to the operation of the fertiliser markets in Africa. In some African 444 countries barriers to the fertiliser market include restrictions on who is allowed to import and 445 sell fertiliser in certain parts of the countries. Some countries also have restrictive business 446 policies such as tax and non-tariff regimes which deter potential investors from investing and trading in fertiliser supply on national or regional scales (USAID and IFDC, 2015).

There have been many policy changes in most sub-Saharan African countries, including the 449 liberalisation of agricultural input and output markets. One example of these was the Structural 450 Adjustment Programmes, through which governments stopped controlling prices of fertilisers. 451 This enabled the private sector to take control over fertiliser markets (Marquis et al., 2013). 452 Several policies have been implemented following the New Partnership for Africa's Development (NEPAD) of the African Union with the view of promoting fertiliser demand and supply (Marquis et al., 2013). One such initiative was the opening of the region to allow fertiliser supply. For example, Ethiopia opened up for investment in the fertiliser manufacturing industry including granting a mining concession to the Allana Potash company, which sought to produce 1 million tonnes/year of muriate of potash (MOP) at their Danakhil mine. The DRC has also attracted investment for the Sintouka potash project from Australia to develop a mine in the DRC, which was expected to begin production of 1.8 million tonnes/year by 2015 460 (Marquis et al., 2013), although this has been delayed (USGS, 2019).

Another policy decision that has been made in many African countries is the strengthening of 462 the agro-dealer sector to improve the quality of their service delivery. This was done to increase 463 sales and access to the local farming communities. These initiatives included providing credit 464 guarantees and loans to the upcoming agro-dealers so that they can import and distribute fertilisers more easily. For example, in Kenya, Rwanda, Burundi, Tanzania, and Ghana, a not- 
for-profit organisation called the One Acre Fund offers loans for fertiliser and seeds to local

467 farmers with a minimal interest repayment, which is used to cover operational costs.

468 In addition, some governments and their development partners have also committed themselves 469 to improve the market linkages for vulnerable communities through the Africa Fertilizer and 470 Agribusiness Partnership (AFAP). Founded in 2011 by the NEPAD, AGRA, IFDC, the African 471 Development Bank (ADB) and the Agricultural Market Development Trust, AFAP's main goal 472 has been to provide targeted support to the fertiliser supply chain. This is an initiative that 473 operates mainly in Ghana, Ethiopia, Tanzania, Kenya, and Mozambique, and enables private 474 sector participation in fertiliser market development by supporting them with finances for 475 fertiliser imports/production, blending, and supply to vulnerable communities such as 476 smallholder farmers, local agro-dealers and fertiliser warehouses.

477 In a related development, other governments established fertiliser subsidies as a vehicle of 478 promoting the purchase of fertiliser at low prices and increasing access to the poor rural farming 479 communities. For example, in Malawi, the Government introduced the targeted farm input 480 fertiliser subsidy programme (FISP) in the early 2000s to help vulnerable farmers. Under this 481 initiative, Government subsidises heavily the prices of fertiliser and seeds so that farmers can 482 purchase the fertiliser and other inputs at lower prices from the agro-dealers. Fertiliser is 483 supplied to rural areas mainly through the state-owned Agriculture and Marketing Cooperation 484 (ADMARC) and the Smallholder Farmers Fertiliser Revolving Fund of Malawi (SFFRM) and 485 other private traders. However, this initiative faces challenges including over-dependency on 486 donor funding (Chirwa and Dorward, 2013) and a long fertiliser supply chain, and uncertainty 487 over its sustainability from the ports to the farmers.

488 In addition, Ott (2012) adds that the farmgate fertiliser price is controlled by various factors 489 including the synergies between demand and supply which are further subject to world 
economic factors, such as transport costs, raw materials, and commodity prices, as well as

491 population growth. For example, Malawi's geographic location as a land-locked country greatly contributes to higher fertiliser costs than in neighbouring countries such as Tanzania and Mozambique. Malawi relies on three major seaports, namely Nacala and Beira (Mozambique), Dar es Salaam (Tanzania), and to some extent Durban (South Africa). Marquis et al. (2013) observed that this problem is also faced by other sub-Saharan African countries, thereby increasing the prices of fertilisers to US $\$ 200 /$ tonne higher than free on board (fob) prices on the global markets. Therefore, additional costs apart from the purchasing prices also originate from importation through neighbouring countries' ports. Transport costs from the port to Malawi's capital, Lilongwe, where the fertiliser is delivered, blended, and redistributed countrywide, are US\$50 to >US\$200 per tonne.

4.2.4. Reduce: reduce inorganic fertiliser use by increasing organic fertiliser use in large-scale food production

Technological methods are being developed to recover nutrients from food and farming waste that have potassium content. For instance, in China, where food security is at the top of the national policy agenda, reduction in self-sufficiency in food production, population growth, limited cropland, and growing urbanisation are seen as trends threatening future food security

507 (He et al., 2017). Limitations in the domestic supply of fertiliser inputs to farms in China are 508 recognised with policies to stabilise fertiliser consumption (Bai et al., 2016). Bai et al. (2016) 509 report that the Chinese government initiated a policy of 'Zero Fertiliser Growth by 2020' to 510 reduce the use of inorganic fertilisers in farming. Bai et al. (2016) suggest that potassium can 511 be applied to cropland in a form of manure from animal farming to replace inorganic potassium 512 fertilisers, although these policies are yet to be proved effective.

513 The major premise of this approach is to link two types of large-scale, industrialised food 
514 productions (animal and crop) by diverting by-products of meat production as inputs into crop

515 production. Potentially, the same can be replicated in the countries of the Global South even at smaller farming scales. Recycling manure and recovery of nutrients for fertiliser production

517 divert production away from mineral-based potassium fertiliser and increases organic fertiliser

518 production. However, this system also has its limitations, as large-scale meat production

519 requires animal feed input and relies on crop production, and harmful residues from veterinary

520 medications may cause problems. Overall, meat production is recognised as the most damaging

521 for the environment, as a major contributor to global carbon emissions, although it does improve

522 soil carbon sequestration.

\subsubsection{Reuse: reuse organic and inorganic fertiliser in close-cycle agricultural systems}

524 Currently, there are constrained applications of potassium recycling. Potassium follows a one525 way stream from extraction to use in agriculture, consumption, and disposal ultimately via river 526 drainage systems into the ocean. Potassium can be applied to soil not only from mineral-based 527 fertilisers, but also from manure, crop residue, and compost (Sheldrick and Lingard, 2004; PDA, 2008; DEFRA, 2010; Dawson and Hilton, 2011; Elser and Bennett, 2011). To maintain soil quality, methods such as agroforestry can be used (Binam et al., 2014). Studies

530 acknowledge that due to minimal use of commercial fertilisers and increasing agroforestry

531 techniques, small-holder farmers can improve soil quality through the utilization of green manure and compost (Binam et al., 2014).

533 For organic farming, conventional chemical fertilisers are not used, and nutrient management focuses on nutrient recycling through integrated management of crop and livestock production

535 (Nowak et al., 2015). Importantly, these practices promote local mass flows, exchanging 536 materials from livestock to crop production and designing a holistic approach to farming at a 537 local level to maintain soil quality and enhance food production (PDA, 2008; Nowak et al., 
538 2015). Organic farming actively uses mined potassium fertilisers, which are acceptable where 539 need can be justified, providing their production avoids chemical processing (Soil Association, 540 2003; PDA, 2008). There are clear opportunities for promoting integrated farming systems in 541 developing countries and engaging with organic farming principles.

\subsubsection{Recycle nutrients: recycle farming and food waste for fertiliser production}

543 Studies on recycling and recovery of nutrients from food waste or the animal food chain suggest

544 promising recovery rates of valuable NPK nutrients and reapplication for food and crop 545 production (Zheng et al., 2020). Advancement of nutrient recycling technologies from farming 546 waste can aid in closing the loop for nutrients and reduce the loss of nutrients (Jurgilevich et 547 al., 2016). However, because of natural losses (given that soil is an open system), inorganic 548 fertilisers cannot be fully replaced with recycled nutrients, but supplement the recovery of 549 nutrient material (see Bai et al., 2016). Elser and Bennett (2011) report that valuable nutrients, 550 potentially usable in agriculture, are lost with food waste; and as much as $40 \%$ of food is wasted 551 by households in developed countries (Mirabella et al., 2014). Capturing the nutrients from 552 composting of food waste presents another route for recycling potassium for farming. Recycling 553 food waste in developing countries, especially in populous urban areas, can be added to nutrient 554 recycling that supplies peri-urban farming. Here, technologies around anaerobic digestion and 555 valorisation of food waste with the participation of food retailers could prove useful $(\mathrm{Ng}$ et al., 556 2019).

\section{Discussion}

559 Based on the study of potassium supply, we identify three main challenges to the 560 implementation of circular economy principles in developing countries: technological, market, 
and institutional factors. Our research adds to the growing body of research on barriers to circular economy implementation (Upadhyay, 2021b).

563 Firstly, in the context of technology, although advancement of mineral exportation and 564 production, as well as improvement of farm and waste techniques to improve recovery at farm 565 level, are ongoing, there is still room for improving the recycling of nutrients from agriculture 566 and scaling up these technologies for availability to farmers in the Global South. Tilton et al. 567 (2018) suggest that support of new technologies and innovation is the paramount solution to 568 short and long-term shortages of resources, as this solution can enhance efficiencies of primary 569 production and recycling and develop substitutes to existing resources.

570 Secondly, with regards to the market factors, there are many market challenges within the 571 mineral and food systems that relate to mineral investment and distribution of fertilisers to 572 farmers in developing countries. There is a need for a systematic approach to the development 573 of agriculture in the Global South, including investment to improve infrastructure and availability of credit including the development of market mechanisms to drive affordable trade 575 in fertilisers. Thirdly, institutional challenges in the Global South relate to the governance of mineral and

577 food production, including legislation, investment regimes, taxation, and sector regulation. 578 Sohn (2006) notes that a favourable institutional environment favours certain mineral 579 production growth. Thus, countries in the Global South could promote investment and 580 development of potassium mining to encourage local potash production for agriculture.

581 To address the three challenges, the six approaches proposed in our research provide a structure 582 for policy formulation and can be used in combination. These approaches integrate two major 583 paradigms of modern food production, one that relies on industrialised agriculture and depends 584 on large-scale mono food production and the second that promotes small-scale food production 
and relies on a combination of farm practices and encourages amongst others organic production (Sonnino and Marsden, 2006). These conventional and alternative agri-food systems both have a place in developed countries and thus potassium fertilisers supply should adjust to the evolving food production patterns (Manning and Theodoro, 2020).

Applying CE principles to the potassium life cycle demonstrates high levels of food waste in

590 developed countries that require adjustments in the generation and utilization of food and 591 farming waste (Mirabella et al., 2014). Neither the industrialised food system nor the alternative 592 production system can substantially reduce the use of inorganic fertilisers and offer a 593 completely closed cycle without compromising farming cost, soil quality, and food production 594 rates.

Industrialised, large-scale, and export-oriented agri-food production is linked to industrialised 596 global mineral supply, dominated by developed country players. This system overlooks the 597 interests of poor, small-holder farmers in the Global South due to differences in production 598 scales, investment, and market power. Government and international organisations could be 599 supporting regional fertiliser supply in developing countries by: a) promoting conventional and

600 alternative potassium discovery and production domestically and supporting agro-geological 601 research; b) encouraging transparency of market information to improve fertiliser markets; c) 602 supporting agri-food research, application of nutrient reuse and recycling and encouraging 603 sustainable farming practices; d) enhancing resource efficiency practices through food and 604 farming waste recycling for nutrient recovery. It is desirable for companies starting potassium 605 extraction projects in the Global South to enter into collaborations with regional partners to 606 address inefficient farming, food insecurity and promote the development of fertiliser markets, 607 effective soil management, and food production.

608 There are limitations to this study. First, it is based on secondary data analysis only, and it lacks 
609 primary qualitative and quantitative data collection on specific circumstances of potassium 610 supply limitations and solutions in individual countries, regions, or mine projects. Further 611 research could examine how potassium mining projects in the Global South can contribute to 612 improving regional food security and assisting small-holder farmers to improve farming yield 613 and incomes using primary data - but at this time there are no such mining projects. Second, 614 the study takes a global, macro view and does not examine what the potassium life cycle would 615 be at a meso level of a region or micro level of an organisation such as a mine, farm, or fertiliser 616 producer with an application to specific types of food production. Further research could 617 investigate collaboration between small-holder farming and small-scale mining leading to 618 potassium fertiliser or remineraliser production. Finally, future studies could compare the 619 management of potassium supply between countries, looking at institutional factors that are 620 conducive to SDG 1 No Poverty and SDG 2 Zero Hunger through efficient fertiliser supply. 621 Further research can examine how to overcome barriers and hindrances to the implementation 622 of circular economy principles in developing countries.

\section{6. Conclusions}

625 We suggest that the answer to improving the use of potassium for optimised yields of agri-food 626 production in the Global South can be found in a hybrid solution that advances both 627 conventional agri-food production and a small-holder alternative system. Agri-food production 628 using conventional food growing and processing technologies and associated large-scale mined 629 potassium production will continue to strengthen food production industries in the Global 630 South. Within this system, the search for new large-scale potassium deposits and investment 631 into their exploitation will increase the potassium supply in the Global South. As an alternative 632 to large-scale conventional food production, a small-holder food production system uses 
633 closed-cycle farming production approaches and, de facto, $\mathrm{CE}$ principles of reuse, recycle

634 nutrients on farms. This alternative system can be associated with small-scale production of

635 mined potassium using small-scale mining, alternative sources of $\mathrm{K}$, and small-scale processing

636 methods - this solution would require scaling up of technologies that would be affordable to

637 small-holder farmers in the Global South.

638 Finally, regional cooperation for the development of regional fertiliser production and

639 distribution is essential in regions of potential domestic potash production such as in East Africa

640 to benefit the regional farming communities and aid in the expansion of regional fertiliser

641 markets. If policy makers are guided by circular economy principles, at all scales as suggested

642 in this study, appropriate and effective options that improve potassium nutrient supply for crop

643 production can be considered for different economic and social circumstances.

\section{References}

646

647

648

649

650

651

652

653

654

655

656

657

658

659

660

661

662

663

664

665

666

667

668

Achilleos, G.A. (2011). The Inverse Distance Weighted interpolation method and error propagation mechanism - creating a DEM from an analogue topographical map. Journal of Spatial Science, 56: $283-304$.

Al Rawashdeh, R. and Maxwell, P. (2014). Analysing the world potash industry. Resources Policy, 41: 143-151.

Al Rawashdeh, R., Xavier-Oliveira, E., Maxwell, P. (2016). The potash market and its future prospects. Resources Policy, 47: 154-163.

Ali, S.H., Giurco, D., Arndt, N., Nickless, E., Brown, G., Demetriades, A., Durrheim, R., Eriquez, M.A., Kinnard, J., Littleboy, A., Meinert, L.D., Oberhänsli, R., Salem, J., Schodde, R., Schneider, G., Vidal, O., Yakovleva, N. (2017). Mineral supply for sustainable development requires resource governance. Nature, 543(7645): 367-372.

Anglo American (2020) Polyhalite https://www.angloamerican.com/products/polyhalite (accessed 17th December 2020).

Bai, Z., Ma, L., Jin, S., Ma, W., Velthof, C.L., Oenema, O., Liu, L., Chadwick, D., Zhang, F. (2016). Nitrogen, phosphorus, and potassium flows through the manure management chain in China. Environmental Science and Technology, 50: 13409-13418.

Bakken, A.K., Gautneb, H., Sveistrup, T., Myhr, K. (2000) Crushed rocks and mine tailings applied as $\mathrm{K}$ fertilizers on grassland. Nutrient Cycling in Agroecosystems, 56(1): 53-57.

Binam, J.N., Tonyé, J., Njankoua wandji, Nyambi, G., Akoa, M. (2004). Factors affecting the technical efficiency among smallholder farmers in the slash and burn agriculture zone of Cameroon. Food Policy, 29: 531-545.

Blomsma, F. and Brennan, G. (2017). The emergence of circular economy: A new framing around prolonging resource productivity. Industrial Ecology, 21 (3): 603-614. 
Braungart, M., McDonough, W., Bollinger, A. (2007). Cradle-to-cradle design: creating healthy emissions - a strategy for eco-effective product and system design. Journal of Cleaner Production, 15 (13): 1337-1348.

Breure, A.M., Lijzen, J.P.A., Maring, L. (2018). Soil and land management in a circular economy. Science of the Total Environment, 624: 1125-1130.

Bridge, G., Barr, S., Bouzarovski, S., Bradshaw, M., Brown, E., Bulkeley, H., Walker, G. (2018). Energy and Society: A Critical Perspective, Routledge: London.

Bridgens, B., Powell, M., Farmer, G., Walsh, C., Reed, E., Royapoor, M., Gosling, P., Hall, J., Heidrich, O. (2018). Creative upcycling: Reconnecting people, materials and place through making. Journal of Cleaner Production, 189: 145-154.

British Geological Survey (BGS) (2011). Potash. Mineral Planning Factsheet. https://www.bgs.ac.uk/downloads/start.cfm?id=1367 (accessed 11 March 2017).

Bryman, A. and Bell, E. (2015). Business Research Methods. Oxford: Oxford University Press. $4^{\text {th }}$ edition.

Bumb, B.L. and Baanante, C.A. (1996). Role of Fertilizers in Sustaining Food Security and Protecting the Environment to 2020. International Food Policy Research Institute. Food, Agriculture and Environment Discussion $\quad$ Paper 17. http://ebrary.ifpri.org/utils/getfile/collection/p15738coll2/id/125603/filename/125634.pdf (accessed 14 October 2019).

Canter, C.E., Blowers, P., Handler, R., Shonnard, D.R. (2015). Implications of widespread algal biofuels production on macronutrient fertilizer supplies: Nutrient demand and evaluation of potential alternate nutrient sources. Applied Energy, 143: 71-80.

Carraresi, L., Berg, S., Bröring, S. (2018). Emerging value chains within the bioeconomy: Structural changes in the case of phosphate recovery. Journal of Cleaner Production, 183: 87-101.

Chirwa, E. and Dorward, A. (2013). Agricultural input subsidies: Changing theory and practice. In: Ephraim Chirwa and Andrew Dorward (2013). Agricultural Input Subsidies: The Recent Malawi Experience. Chapter 2. 31pp. DOI:10.1093/acprof:oso/9780199683529.003.0002.

Ciceri, D., Manning, D.A.C., Allanore, A. (2015). Historical and technical developments of potassium resources. Science of the Total Environment, 502: 590-601.

Cordell, D., Drangerta, J.-O., White, S. (2009). The story of phosphorus: Global food security and food for thought. Global Environmental Change, 19, 292-305.

Dawson, C.J. and Hilton, J. (2011). Fertiliser availability in a resource-limited world: Production and recycling of nitrogen and phosphorus. Food Policy, 36: S14-S22.

Department for Food, Agriculture and Rural Affairs (DEFRA) (2010). Fertiliser Manual (RB209), $8^{\text {th }}$ edition. http://www.ahdb.org.uk/documents/rb209-fertiliser-manual-110412.pdf (accessed 11 March 2017).

Dmitrieva, D., Ilinova, A., Kraslawski, A. (2017). Strategic management of the potash industry in Russia. Resources Policy, 52: 81-89.

Dong, L., Zhang, H., Fujita, T., Ohnishi, S., Li, H., Fujii, M., Dong, H. (2013). Environmental and economic gains of industrial symbiosis for Chinese iron/steel industry: Kawasaki's experience and practice in Liuzhou and Jinan. Journal of Cleaner Production, 59: 226-38.

Ellen MacArthur Foundation (2013). Towards the Circular Economy: Economic and Business Rationale for an Accelerated Transition. www.ellenmacarthurfoundation.org/publications (accessed 24 October 2019).

Ellen MacArthur Foundation (2019). Completing the Picture: How the Circular Economy Tackles Climate Change. www.ellenmacarthurfoundation.org/publications (accessed 14 October 2019).

Elser, J. and Bennett, E. (2011). A broken biochemical cycle. Nature, 6 October 2011, 478: 29-31.

European Commission (EU) (2014). Towards a Circular Economy: A Zero Waste Programme for Europe. Communication from the Commission to the European Parliament. the Council, the European Economic and Social Committee and the Committee of the Regions, Brussels (EN). https://ec.europa.eu/environment/circular-economy/pdf/circular-economy-communication.pdf (accessed 14 October 2019).

European Commission (EU) (2015). Closing the Loop - An EU Action Plan for the Circular Economy. Communication from the Commission to the European Parliament. The Council, the European Economic and Social Committee and the Committee of the Regions. https://eur- 
European Union (EU) (2018). Report on Critical Raw Materials and the Circular Economy. EU, Brussels. https://ec.europa.eu/growth/sectors/raw-materials/specific-interest/critical_en (accessed 14 October 2019).

FAOSTAT (2001). Food and Agriculture Organization of the United Nations. Available from http://www.fao.org/faostat/en/\#data.

Financial Times (FT) (2016a). PotashCorp and Agrium agree near-\$30bn fertilisers merger. Financial Times, 12 September 2015. https://www.ft.com/content/b1c46048-78d5-11e6-a0c6-39e2633162d5 (accessed 11 March 2017).

Financial Times (FT) (2016b). Sirius targets September start for UK potash mine. Financial Times, 26 July 2016. https://www.ft.com/content/edb8623a-3f95-11e6-8716-a4a71e8140b0 (accessed 11 March 2017).

Food and Agriculture Organization of the United Nations (FAO) (2019). The State of Food Security and Nutrition in the World. FAO, Rome. http://www.fao.org/3/ca5162en/ca5162en.pdf (accessed 14 October 2019).

Food and Agriculture Organization of the United Nations (FAO) (2016). World Fertilizer Trends and Outlook to 2019. Summary Report. FAO, Rome. http://www.fao.org/3/a-i5627e.pdf (accessed 11 March 2017).

Food and Agriculture Organization of the United Nations (FAO) (2015). World Fertiliser Trends and Outlook to 2018. FAO, Rome. 2015. http://www.fao.org/3/a-i4324e.pdf (accessed 14 October 2019).

Forbes (2019). World Class Potash Project in Eritrea Moves Closer to Development. Forbes, Published 15 January 2019. https://www.forbes.com/sites/timtreadgold/2019/01/15/world-class-potashproject-in-eritrea-moves-closer-to-development/ (accessed 24 October 2019).

Gaustad, G., Krystofik, M., Bustamante, M., Badami, K. (2018). Circular economy strategies for mitigating critical material supply issues. Resources, Conservation \& Recycling, 135: 24-33.

Geissdoerfer, M., Savaget, P., Bocken, N.M.P., Hultink, E.J. (2017). The Circular economy: A new sustainability paradigm? Journal of Cleaner Production, 143: 757-768.

Gilbert, N. (2012). Dirt poor: The key in tackling hunger in Africa is enriching its soil. The big debate is about how to do it. Nature, 29 March 2012, 483: 525-527.

Grantham, J. (2012). Be persuasive. Be brave. Be arrested (if necessary). Nature, 14 November 2012, 491(7424): 303.

He, C., Liu, Z., Xu, M., Ma, Q., Dou, Y. (2017). Urban expansion brought stress to food security in China: Evidence from decreased cropland net primary productivity. Science of the Total Environment, 576: 660-670.

Heffer, P. and Prud'homme, M. (2016). Fertiliser Outlook 2016-2020. International Fertilizer Industry Association: Paris. http://www.fertiliser.org (accessed 11 March 2017).

Heidrich, O., Cherry, B., Yakovleva, N., Manning, D. A. C., Ford, A. (2018). Special K: potassium production. Transform IEMA, 18(12): 23-36.

Hite, J.R. and Japakasetr, T. (1979). Potash deposits of the Khorat Plateau, Thailand and Laos. Economic Geology, 74: 448-454.

International Potash Institute (IPI) (2016). Balancing Use of Fertilizers with Potassium. International Potash Institute: Switzerland. http://www.ipipotash.org/udocs/461-balancing-use-fertilizerspotassium-en.pdf (accessed 11 March 2017).

Jasinski, S.M. (2011). Mineral Commodity Summaries: Potash. US Geological Survey. http://minerals.usgs.gov/minerals/pubs/commodity/potash (accessed 11 March 2017).

Jurgilevich, A., Birge, T., Kentala-Lehtonen, J., Korhonen-Kurki, K., Pietikäinen, J., Saikku, L., Schösler, H. (2016). Transition towards circular economy in the food system. Sustainability, 8: 69, doi:10.3390/su8010069.

Kelly, V.A. (2006). Factors Affecting Demand for Fertilizer in Sub-Saharan Africa. Agriculture and Rural Development Discussion Paper 23. World Bank: Washington, DC.

Kemp, S.J., Smith, F.W., Wagner, D., Mounteney, I., Bell, C.P., Milne,C.J., Gowing, C.J.B., Pottas, T.L. (2016). An improved approach to characterize potash-bearing evaporite deposits, evidenced in North Yorkshire, United Kingdom. Economic Geology, 111: 719-742.

Kinnunen, P.H.M. and Kaksonen, A.H. (2019). Towards circular economy in mining: Opportunities and 
bottlenecks for tailings valorization. Journal of Cleaner Production, 228: 153-160.

Korhonen, J., Honkasalo, A., Seppälä, J. (2018). Circular economy: The concept and its limitations. Ecological Economics, 143: 37-46.

Larson, B.A. and Frisvold, G.B. (1996). Fertilizers to support agricultural development in sub-Saharan Africa: What is needed and why. Food Policy, 21(6): 509-525.

Leonardos, O., Theodoro, S., Assad, M. (2000). Remineralization for sustainable agriculture: A tropical perspective from a Brazilian viewpoint. Nutrient Cycling in Agroecosystems, 56: 3-9.

Lieder, M. and Rashid, A. (2016). Towards circular economy implementation: A comprehensive review in context of manufacturing industry. Journal of Cleaner Production, 115: 36-51.

Luthra, S., Mangla S., Sarkis, J. and Tseng, M. (2019). Resources Melioration and the Circular Economy. Resources Policy, Available at" https://www.journals.elsevier.com/resourcespolicy/call-for-papers (Accessed on 27 Sep. 2019).

Manning, D.A.C. (2010). Mineral sources of potassium for plant nutrition: A review. Agronomy for Sustainable Development, 30: 281-294.

Manning, D.A.C. and Theodoro, S. H. (2020). Enabling food security through use of local rocks and minerals. The Extractive Industries and Society, 7: 480-487.

Manning, D.A.C., Tangtinthai, N., Heidrich, O. (2019). Evaluation of raw material extraction, processing, construction and disposal of cement and concrete products: Datasets and calculations. Data in Brief, 24, 103929.

Marquis, S., Genter, T., Buet A, et al. (2013). International Fertiliser Society, Conference International Fertiliser Society, 4(May): 1-33.

Martey, E., Kuwornu, J.K.M., Adjebeng-Danquah, J. (2019). Estimating the effect of mineral fertilizer use on land productivity and income: Evidence from Ghana. Land Use Policy, 85: 463-475.

McDonough, B. and Braungart, M. (2002). Cradle to Cradle: Remaking the Way We Make Things. $5^{\text {th }}$ ed., Vintage.

Meinert, L.D., Robinson Jr, G.R., Nassar, N.T. (2016). Mineral resources: Reserves, peak production and the future. Resources, 5: 14. doi:10.3390/resources5010014.

Mirabella, N., Castellani, V., Sala, S. (2014). Current options for the valorization of food manufacturing waste: a review. Journal of Cleaner Production, 65: 28-41. https://doi.org/10.1016/j.jclepro.2013.10.051.

Mukuve, F.M. and Fenner, R.A. (2015). The influence of water, land, energy and soil-nutrient resource interactions on the food system in Uganda. Food Policy, 51: 24-37.

Murray, A., Skene, K., Haynes, K. (2017). The circular economy: An interdisciplinary exploration of the concept and application in a global context. Journal of Business Ethics, 140: 369-380.

Ng, K.S., Yang, A., Yakovleva, N. (2019). Sustainable waste management through synergistic utilisation of commercial and domestic organic waste for efficient resource recovery and valorisation in the UK. Journal of Cleaner Production, 227: 248-262.

Nowak, B., Nesme, T., David, C., Pellerin, S. (2015). Nutrient recycling in organic farming is related to diversity in farm types at the local level. Agriculture, Ecosystems and Environment, 204: 17-26.

Ott, H. (2012). Fertilizer markets and its interplay with commodity and food prices. JRC Scientific and Policy Reports (JRC73043). DOI: 10.2791/82136.

Pavuluri, K., Malley, Z., Mzimbiri, M.K., Lewis, T.D., Meakin, R. (2017). Evaluation of polyhalite in comparison to muriate of potash for corn grain yield in the Southern Highlands of Tanzania. African Journal of Agronomy, 5: 325-332.

Potash Development Association (PDA) (2008). Potash for Organic Growers. Leaflet 23. Potash Development Association: York. http://www.pda.org.uk/wp/wp-content/uploads/2015/12/PDA1f23.pdf (accessed 11 March 2017).

Potash Development Association (PDA) (2016). What is potash? The Global Potash (K) Cycle. Potash Development Association: York. http://www.pda.org.uk/what-is-potash/ (accessed $11 \mathrm{March}$ 2017).

PotashCorp (2014). The World's Ten Largest Fertilizer Companies. PortashCorp. Available from: http://www.potashcorp.com/overview/introduction/our-nutrients/worlds-10-largest-fertilizercompanies (accessed 11 March 2017).

Reuters (2018). Kore Potash to tap investors for $\$ 600 \mathrm{mln}$ towards Congo Rep mine. Reuters, Market News, published 29 March 2018. https://www.reuters.com/article/kore-potash-ipo/kore-potash-to- 

2019).

Rhee, S.W. (2016). Beneficial use practice of e-wastes in Republic of Korea, The Tenth International Conference on Waste Management and Technology (ICWMT). Procedia Environmental Sciences, 31: $707-714$.

Roberts, S. and Vilakazi, T. (2014). Regulation and Rivalry in Transport and Fertilizer Supply in Malawi, Tanzania and Zambia. Centre for Competition, Regulation and Economic Development, University of Johannesburg.

Roberts, T.L. (2009). The role of fertilizer in growing the world's food. Better Crops, 93(2): 12-15. http://www.ipni.net/publication/bettercrops.nsf/0/D21DBC864569368D85257980006FC3DB/\$FI LE/Better\%20Crops\%202009-2\%20p12.pdf (accessed 11 February 2020).

Royal Society of Arts (RSA) (2013). Investigating the Role of Design in the Circular Economy. The Great Recovery: Redesigning for the Future. London: RSA.

Sanchez-Lopez, M.D. (2019). From a white desert to the largest world deposit of lithium: Symbolic meanings and materialities of the Uyuni Salt Flat in Bolivia. Antipode, 51(4): 1318-1339.

Sanchez, P. (2002). Soil fertility and hunger in Africa. Science, 15 March 2002, 295: 2019-2020.

Setianto, A. and Triandini, T. (2013). Comparison of kriging and inverse distance weighted (IDW) interpolation methods in lineament extraction and analysis. Journal of Southeast Asian Applied Geology, 5(1): 21-29.

Sheahan, M. and Barret, C.B. (2017). Ten striking facts about agricultural input use in Sub-Saharan Africa. Food Policy, 67, 12-25.

Sheldrick, W.F. (2001). The development of a nutrient audit model for estimating time-series soil nutrient balances at the national, regional and global scales. Newcastle upon Tyne: University of Newcastle upon Tyne, (PhD Thesis).

Sheldrick, W.F. and Lingard, J. (2004). The use of nutrient audits to determine nutrient balances in Africa. Food Policy, 29: 61-98.

Sheldrick, W.F., Syers, J.K., Lingard, J. (2002) A conceptual model for conducting nutrient audits at national, regional and global scales, Nutrient Cycling in Agrosystems, 62: 61-67.

Sohn, I. (2006). Long-term projections of non-fuel minerals: We were wrong, but why? Resources Policy, 30: 259-284.

Soil Association (2003). Soil Management for Organic Farms. Soil Association Technical Guides. Soil Association: Bristol. https://www.soilassociation.org/media/4332/sa-tech-guide-soil.pdf (accessed 11 March 2017).

Sonnino, R. and Marsden, T. (2006). Beyond the divide: rethinking relationship between alternative and conventional food networks in Europe. Journal of Economic Geography, 6(2): 181-199.

Tangtinthai, N., Heidrich, O., Manning, D.A.C. (2019). Role of policy in managing mined resources for construction in Europe and emerging economies. Journal of Environmental Management, 236: 613-621.

Tavares, L. de F., Mundstock, A., de Carvalho, X., Camargo, L. G. B., Pereira, S. G. de F., Cardoso, I. M. (2018). Nutrients release from powder phonolite mediated by bioweathering actions. International Journal of Recycling of Organic Waste in Agriculture, 7: 89-98.

Tilton, J.E., Crowson, P.C.F., DeYoung Jr, J.H., Eggert, R.G., Ericsson, M., Guzmán, J.I., Humphreys, D., Lagos, G., Maxwell, P., Radetzki, M., Singer, D.A., Wellmer, F.W. (2018) Public policy and future mineral supplies. Resources Policy, 57: 55-60.

United Nations (UN) (2016). The Sustainable Development Agenda. United Nations: New York. http://www.un.org/sustainabledevelopment/development-agenda (accessed 11 March 2017).

United Nations (UN) (2018). Population data. United Nations : New York. http://www.un.org (accessed 1 July 2018).

United Nations Environment Programme (UNEP) (2018). Programme Performance Report 2018: Putting the Environment at the Heart of People's Lives. UNEP, Nairobi. https://www.unenvironment.org/annualreport/2018/index.php\#cover (accessed 14 October 2019).

Upadhyay, A., Kumar, A., Akter, S. (2021a). An analysis of UK retailers' initiatives towards circular economy transition and policy-drivers and directions. Clean Technologies and Environmental Policy, https://doi.org/10.1007/s10098-020-02004-9.

Upadhyay, A., Laing, T., Kumar, V., Dora, M. (2021b). Exploring barriers and drivers to the 
implementation of circular economy practices in the mining industry, Resources Policy, 72, 102037.

US Geological Survey (USGS) (2009). Potash. Mineral Commodities Program. http://minerals.usgs.gov/minerals/pubs/commodity/potash/mcs-2009-potas.pdf (accessed 11 March 2017).

US Geological Survey (USGS) (2016). Potash. Mineral Commodities Program. United Nations Geological Survey: Reston, USA. http://minerals.usgs.gov/minerals/pubs/commodity/potash/mcs-2016-potas.pdf (accessed 11 March 2017).

US Geological Survey (USGS) (2019). Potash. Mineral Commodities Summary. https://www.usgs.gov/centers/nmic/potash-statistics-and-information (accessed 14 October 2019).

USAID and IFDC (2015). Developing Competitive Fertilizer Markets in Africa: Policy Lessons from FTF Country Assessments. https://ifdcorg.files.wordpress.com/2016/05/synthesis-report-ftfcountry-fertilizer-assessment-final-draft-1.pdf (accessed 11 February 2020).

Van Straaten, P. (2002). Rocks for Crops: Agrominerals in sub-Saharan Africa. ICRAF, Nairobi, Kenya, $338 \mathrm{pp}$.

Vazquez-Brust, D.A. and Sarkis, J. (2012). Green Growth: Managing the Transition to a Sustainable Economy: Learning by Doing in East Asia and Europe. Springer: Netherlands.

Villalba, G., Liu, Y., Schroder, H., Ayres, R.U. (2008). Global phosphorus flows in the industrial economy from a production perspective. Journal of Industrial Ecology, 12(4): 557- 569.

Weinzettel, J., Hertwich, E.G., Peters, G.P., Steen-Olsen, K., Galli, A. (2013). Affluence drives the global displacement of land use. Global Environmental Change, 23, 433-438.

Wellington, T.A.A. and Mason, T.E. (2014). The effects of population growth and advancements in technology on global mineral supply. Resources Policy, 42: 73-82.

Winans, K., Kendall, A., Deng, H. (2017). The history and current application of the circular economy concept. Renewable and Sustainable Energy Reviews, 68: 825-833.

World Health Organization (WHO) (2012). Guideline: Potassium Intake for Adults and Children. World Health Organization (WHO): Geneva. http://www.who.int/nutrition/publications/guidelines/potassium_intake_printversion.pdf (accessed 12 March 2017).

Wu, X.D., Guo, J.L., Han, M.Y., Chen, G.Q. (2018). An overview of arable land use for the world economy: From source to sink via the global supply chain. Land Use Policy, 76, 201-214. https://doi.org/10.1016/j.landusepol.2018.05.005

Zheng, T., Wang, B., Rajaeifar, M.A., Heidrich, O., Zheng, J., Liang, Y. and Zhang, H. (2020) How government policies can make waste cooking oil-to-biodiesel supply chains more efficient and sustainable, Journal of Cleaner Production, 263: 121494. 